\title{
Biofertigation of Forage With Effluents From a Cattle Slaughterhouse Green Line: Impacts on Physical-Chemical Indicators of Soil Quality and on Production Biomass
}

\author{
Joaquim Jose de Carvalho ${ }^{1}$, José Maria Rodrigues da Luz $^{2}$, Jacqueline Henrique ${ }^{1}$, José Geraldo Delvaux Silva ${ }^{3}$, \\ Raphael Bragança Alves Fernandes ${ }^{2}$, S. S. Ribeiro ${ }^{3} \&$ José Expedito Cavalcante da Silva ${ }^{1}$ \\ ${ }^{1}$ Universidade Federal do Tocantins, Palmas, TO, Brazil \\ ${ }^{2}$ Universidade Federal de Viçosa, MG, Brazil \\ ${ }^{3}$ CEULP/ULBRA, Palmas, TO, Brazil \\ Correspondence: José Expedito Cavalcante da Silva, Universidade Federal do Tocantins, TO, Brazil. Tel: \\ 55-063-3232-8007.E-mail: jecs@mail.uft.edu.br
}

Received: March 11, 2018

Accepted: May 11, $2018 \quad$ Online Published: June 15, 2018

doi:10.5539/jas.v10n7p359

URL: https://doi.org/10.5539/jas.v10n7p359

\begin{abstract}
Cattle slaughterhouses are potential causes the environmental impacts, as it require a large volume of water in meat processing, generate large effluents amount, and promote the Cerrado deforestation for animal husbandry. Therefore, we aim was carried out to assess the effects of the soil application of a green line wastewater from a cattle slaughterhouse in the Brachiaria brizantha growth. The M1 and M2 managements did not contain wastewater of slaughterhouse. The wastewater from the $3^{\text {rd }}$ stabilization pond (M3 to M5), from reception box (M6 to M8), and manure (M9 and M10) were used in the biofertigation managements. The physical-chemical indicators levels did not show significant differences $(\mathrm{p}<0.05)$ before soil preparation and after managements. However, biofertigation in the Cerrado soil can provide a mitigation of the leaching of fine soil particles and cations. In addition, maximum nitrogen dose of wastewater provided a higher leaf biomass productivity than commercial nitrogen. Thus, the fertigation with wastewater can reduce the use of water bodies to crops irrigation and the incorporation of new areas with native vegetation to the agricultural production systems.
\end{abstract}

Keywords: wastewater management, soil waste disposal, Brachiaria brizantha, Marandu, manure, stabilization pond.

\section{Introduction}

New forest areas have been incorporated into agricultural production systems, due to the food demand of growing human population (FAO, 2005; ONU, 2013). In Brazil, this agricultural expansion is seen the Cerrado with the replacement of native vegetation by crops and livestock (Andrade, 2002; Cardoso et al., 2011; Costa et al., 2007). The excessive use of agrochemicals, fertilizers, and correctives, the uncontrolled irrigation, soil compaction by trampling of animals, monoculture, and intensive mechanization have contributed to soil and groundwater contamination, and the natural resources degradation (Cunha et al., 2008). To neutralize or mitigate these impacts is necessary to development biotechnologies that can promote the sustainable use of natural resources.

Meat is one of the animal protein sources most consumed by the human population. Brazil has one of the largest cattle herds of the world (IBGE, 2015). However, the meat production is associated with the high water consumption and environmental impacts due to the effluents. In the green line of a cattle slaughterhouse, which assembled effluent from the process of cleaning feces, urine, and vomit, water consumption can be approximately 1,000 liters per animal (Pacheco \& Yamanaka, 2008). Furthermore, the highest water consumption is in the washing of the animals and equipment. In this process, law require the use of fresh and potable water, with minimum contents of residual free chlorine (Pacheco, 2006).

In the Tocantins state, northern Brazil, the annual volume of wastewater of the green line is of 1.000 .000 .0000 to 2.000.000.000 liters, and this large amount of effluents is discharges into the water bodies without treatment (SEPLAN, 2013a). However, most of the Tocantins territory belong to the Cerrado biome, and the state 
agricultural sector accounts for approximately $18 \%$ of its gross domestic product (SEPLAN, 2013a). The preservation of this important Brazilian biome in harmony with this essential economic activity is a great challenge for the Tocantins state and others regions in the tropical region.

The viable alternatives to mitigate negative environmental impacts, in particular, the discharges of wastewater in water bodies are important for environmental sustainability of the livestock (Mendes et al., 2006; Vieira et al., 2009).

The aims of this study were to evaluate the use of effluents of a cattle slaughterhouse green line to reach the nutritional and water requirements of $B$. brizantha $\mathrm{cv}$. Marandu and the impacts of this biofertigation on the physical-chemical indicators of Cerrado soil.

\section{Material and Methods}

\subsection{Site Location and Characterization}

The experiment was carried out on the campus of CEULP/ULBRA, Palmas-Tocantins, Brazil that presents 254 $\mathrm{m}$ of altitude and geographic coordinates of $10^{\circ} 16^{\prime} 34.16^{\prime \prime} \mathrm{S}$ and $48^{\circ} 20^{\prime} 05.03^{\prime \prime} \mathrm{W}$ (Figure 1).

The climate of this region is humid subhumid (C2wA'a") with a water deficit in the winter and 1.4 at $1.7 \mathrm{~mm}$ of annual evapotranspiration (Sousa, 2010).

The soil of region was classified as a Red-Yellow Latosol, occurring in a smooth relief and a slope $<5 \%$. Thus, surface runoff is slow and predominantly westbound (SEPLAN, 2013b).

\subsection{The Experiment}

First, vegetation cover was removed, and soil sampling was performed to the soil characterization. Soil sampling was systematic according to the methodology proposed by Raij (2001). Eight samples (A1 to A8) were collected at depths of 0 to 10, 10 to 20, 20 to 30 and 90 to $100 \mathrm{~cm}$ (Figure 1).

Ten treatments of biofertigation managements (M1 to M10) were applied on plots of $1.62 \times 3.00 \mathrm{~m}\left(4.86 \mathrm{~m}^{2}\right)$ spaced $0.20 \mathrm{~m}$ apart in quadruplicate (Figure 1). The forage planting was performed in spaced rows of $1.00 \mathrm{~m}$ inside the plots.

The experiment was arranged in a randomized complete block design with four replications (B1 to B4), two aligned east to west, and two north to south (Figure 1).

After the third plant cutting, new soil samples were obtained. These samples were collected at the center of each experimental plot (M1 to M10). At these collection points, soil resistance to root penetration in depths of 0 to 60 $\mathrm{cm}$ and $2.5 \mathrm{~cm}$ interval was measured with the aid of the penetrometer (Falker-PLG 1020).

The physical-chemical indicators were determined in $20 \mathrm{~g}$ of soil samples.

\subsubsection{Preparation Initial of Soil in Experimental Area}

After soil sampling, the plowing and sorting of the soil with the use of tractor-driven disk plows were performed.

Physical-chemical indicators ( $\mathrm{pH}$, base saturation and cation exchange capacity) contents of the first soil samples were used to the soil acidity adjustment. Hand throwing and use of rake performed the distribution and incorporation dolomitic limestone. In addition, the leveling of area was done.

The limestone application occurred during the dry season (July/2015) with few or no rain. Thus, a water blade was applied in soil for a better limestone distribution in area. 


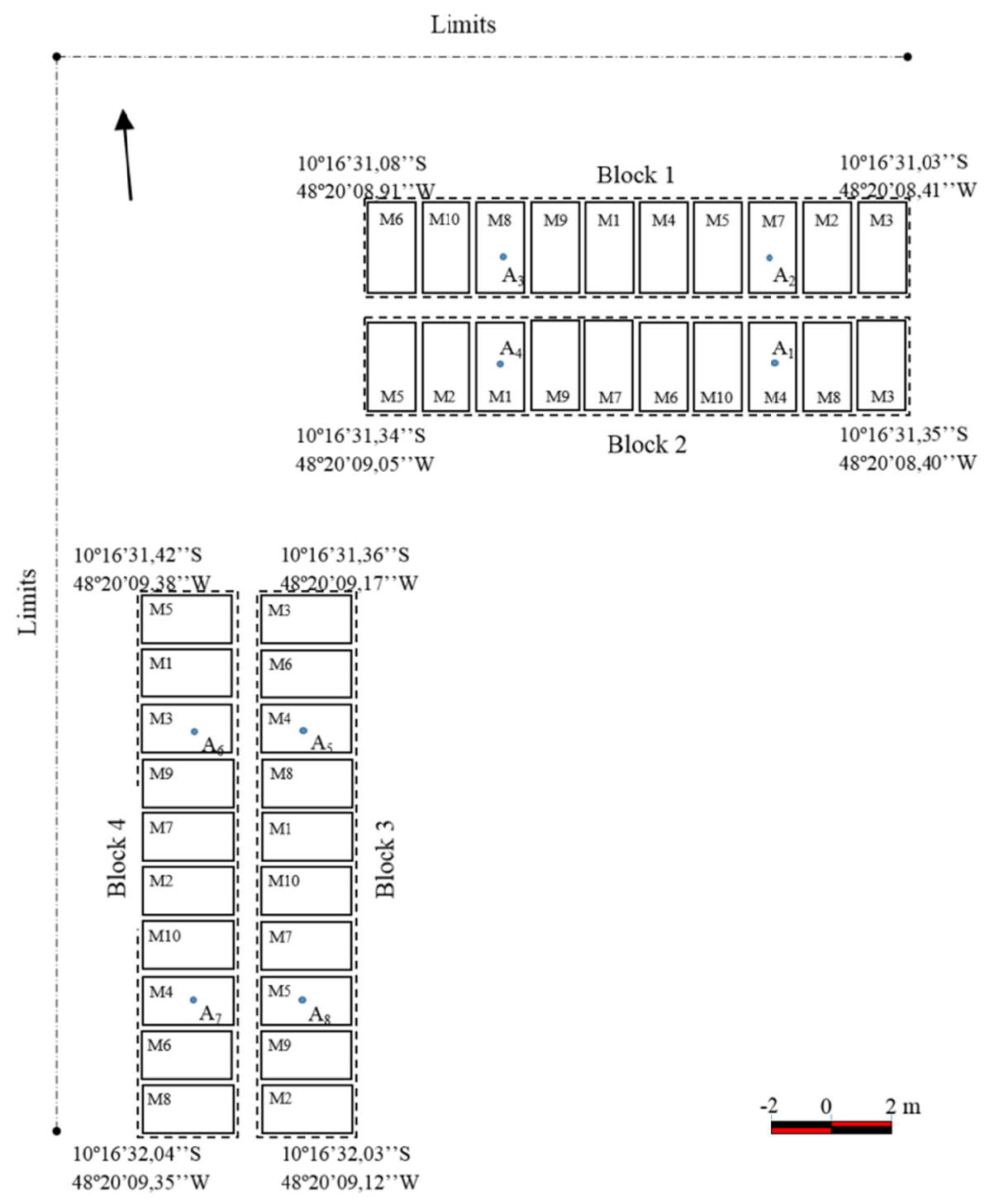

Figure 1. Experimental area showing the distribution of collection points of the soil samples (A1 to A8) and treatments applied with different biofertigation managements (M1 to M10)

\subsubsection{Determination of Total Water Capacity in the Soil and the Water Demand of the Crop}

The total soil water availability (TSW) was determined from the soil texture (Bernardo, 2006).

The water demand of B. brizantha $\mathrm{cv}$ Marandu was measured by monthly data of air temperature, rainfall, and potential evapotranspiration of Palmas/TO/Brazil. A climatological water balance of forage by Thornthwaite \& Mather method was performed with average these variables and TSW.

\subsubsection{Forage Nutritional Demand}

The nutritional demand of B. brizantha was performed with the primary macronutrients level, nitrogen $(\mathrm{N})$, phosphorus pentoxide $\left(\mathrm{P}_{2} \mathrm{O}_{5}\right)$, and potassium oxide $\left(\mathrm{K}_{2} \mathrm{O}\right)$. The nutrients amount was determined from the contents of these elements in the depth of 0 to $20 \mathrm{~cm}$. Commercial fertilizer containing superphosphate (with $18 \% \mathrm{P}_{2} \mathrm{O}_{5}$ ), potassium chloride (with $60 \% \mathrm{~K}_{2} \mathrm{O}$ ) and urea (with $45 \% \mathrm{~N}$ ) was used.

\subsubsection{Forage Water Demand}

A day before sowing (June 22, 2015), a water blade was applied to raise the level of water in the soil to the field capacity. This layer of water was calculated from the estimate of the water depth in the soil between the wilting point and the field capacity. After this first addition of water in the soil, the other additions were estimated as a 
function of the maximum crop evapotranspiration, the irrigation shift ( 3 and 4 days) and the rainfall occurred between biofertigation.

The water blade with or without wastewater/manure was multiplied by plot area and total volume was divided by the capacity of the sprinkler (10 1).

\subsection{Fodder Planting}

B. brizantha cv Marandu seed was purchased in Palmas/TO/Brazil with, respectively, $60.3 \%$ and $80.0 \%$ purity and germination rate. Thus, the cultural value was of $48.24 \%$. In the planting of this forage are use of 1.5 to 2.0 $\mathrm{kg}$ / ha of viable seeds (Embrapa, 1984). In this study, $1.75 \mathrm{~kg} / \mathrm{ha}$ of viable seeds were used.

The planting was carried out (June 24, 2015) with sowing in equidistant lines $(1.00 \mathrm{~m})$. In each plot, we did 3 planting lines in the form of triangular grooves with depth of $4 \mathrm{~cm}$ and $1.62 \mathrm{~m}$ in length. The seeds were distributed in these grooves with spacing of $5 \mathrm{~cm}$ and were covered with a lightly pressed soil layer. This cover was only made to provide wet soil contact with the seeds.

\subsection{Biofertigation Management in the Field Experiment}

The experimental design was performed in completely randomized blocks (B1 to B4) and 10 biofertigation managements (M1 to M10) (Table 1). This table also contains the inputs quantity for each management.

The wastewater used in this experiment were collected in a cattle slaughterhouse of the Paraíso do Tocantins/TO/Brazil city. In this slaughterhouse, the effluents of the green line are channeled to a reception box. The wastewater of this box are separated into two portions through a pumping system. The liquid part is deposited in three stabilization ponds and solid part (manure) is used as fuel in the boiler heating system. Two liters of these wastewaters were collected for physical-chemical indicators determination (Table 2). These analyses were performed according to Standard Methods (APHA, 2005).

The wastewater from the $3^{\text {rd }}$ stabilization pond (M3 to M5) and from reception box (M6 to M8) and the manure (M9 and M10) were used in the biofertigation managements (Table 1). The managements, M1 and M2, did not contain wastewater/manure.

The inputs amount of each parcels was determined by NPK availability in the soil and in the wastewater/manure (Table 2). In addition, the $\mathrm{N}$ content was used to determine the wastewater amount of the biofertigation managements (Tables 1 and 2).

The commercial and wastewater/manure inputs were applied together with the layer of water of artesian well. 
Table 1. Biofertigation Management and quantity of inputs applied in the planting of Brachiaria brizantha cv Marandu

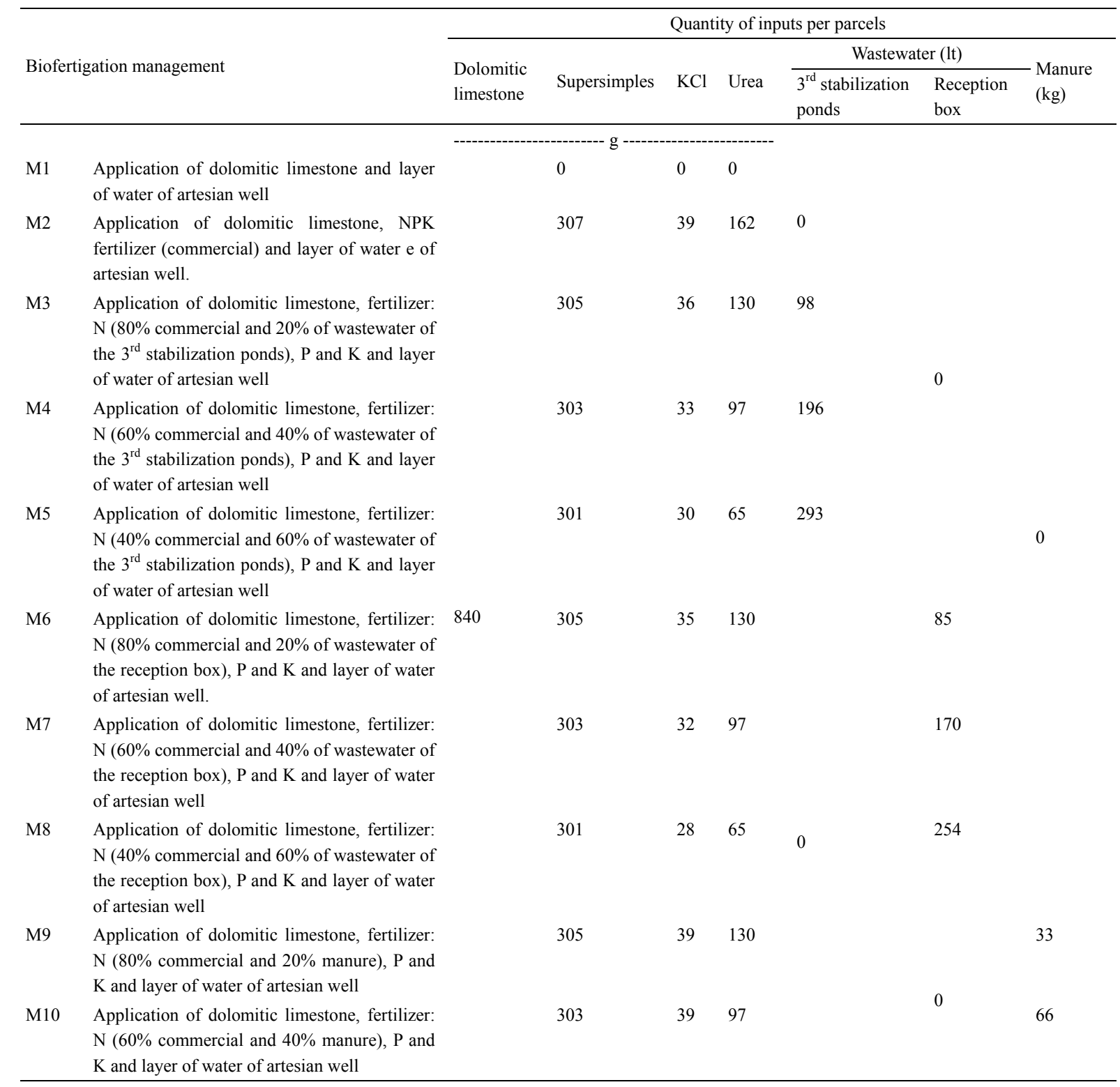


Table 2. Physical-chemical indicators of the green line wastewater of slaughterhouse used in the experiment

\begin{tabular}{|c|c|c|c|c|c|}
\hline \multirow{3}{*}{ Physical-chemical indicators ${ }^{*}$} & \multicolumn{5}{|c|}{ Wastewater of slaughterhouse } \\
\hline & \multirow{2}{*}{ Unity } & $3^{\text {rd }}$ stabilization ponds & Reception box & \multirow{2}{*}{ Unity } & \multirow{2}{*}{$\begin{array}{l}\text { Manure } \\
\text { Amount }\end{array}$} \\
\hline & & \multicolumn{2}{|c|}{ Amount } & & \\
\hline Electric conductivity & $\mu \mathrm{S} / \mathrm{cm}$ & 90 & 110 & - & - \\
\hline Solids & \multirow{2}{*}{$\mathrm{mg} / \mathrm{L}$} & 1.092 & 1.271 & - & - \\
\hline Suspended solids & & 583.823 & 680.231 & - & - \\
\hline $\mathrm{pH}$ & - & 8.2 & 8.05 & - & 8.76 \\
\hline Fat & \multirow[t]{10}{*}{$\%$} & 23 & 46 & $\%$ & 12 \\
\hline Nitrogen & & 149.445 & 172.326 & & 443.789 \\
\hline Organic nitrogen & & 86.541 & 89.441 & & 131.442 \\
\hline Nitrite & & 0.074 & 0.194 & & 3.102 \\
\hline Nitrate & & 2.423 & 4.213 & & 11.413 \\
\hline Ammonia & & 60.424 & 78.476 & & 297.863 \\
\hline Arsenic & & 0.342 & 0.442 & & \multirow{2}{*}{$<0.001^{* *}$} \\
\hline Nickel & & 0.032 & 0.022 & & \\
\hline Chlorine & & 0.034 & 0.041 & & 0.011 \\
\hline Cadmium & & 0.553 & 0.353 & \multirow{11}{*}{$\mathrm{mg} / \mathrm{kg}$} & $<0 \Omega 01^{* *}$ \\
\hline Copper & \multirow[t]{10}{*}{$\mathrm{mg} / \mathrm{L}$} & 0.452 & 0.541 & & -0.001 \\
\hline Iron & & 1.921 & 3.734 & & 1.432 \\
\hline Alumiun & & 0.047 & 0.038 & & \\
\hline Manganese & & 0.002 & 0.012 & & $<0.001^{* *}$ \\
\hline Magnesium & & 0.703 & 0.945 & & \\
\hline Sulfur & & 2.652 & 2.835 & & 0.667 \\
\hline Calcium & & 5.962 & 10.024 & & 1.072 \\
\hline Phosphorus & & 1.584 & 1.982 & & 4.554 \\
\hline Sodium & & 27.122 & 39.252 & & 3.212 \\
\hline Potasium & & 14.223 & 21.421 & & 1.621 \\
\hline Carbon & $\mathrm{g} / \mathrm{L}$ & 2.034 & 2.534 & $\mathrm{~g} / \mathrm{kg}$ & 5.322 \\
\hline
\end{tabular}

Note. ${ }^{*}$ The minerals were determined after a nitroperchloric digestion of the samples.

** Values below the limit of detection.

\subsection{Characterization of Leaf Biomass}

The bromatological composition of the forage is indispensable in the evaluation of the impact of the residuary materials on the agronomic performance of the crop and on the changes of the physical-chemical indicators of the soil fertilization.

The leaf biomass cutting was performed in the center of the parcels $(1.00 \times 0.82 \mathrm{~m})$ to avoid the border effect, with a pruning shears.

The green mass was determined on analytical balance.

The samples in $65^{\circ} \mathrm{C}$ forced-ventilation greenhouses during 72 hours to moisture loss were conditioned.

After cooling to room temperature $\left(25 \pm 5^{\circ} \mathrm{C}\right)$, the air dry mass $(\mathrm{ADM})$ was determined using the analytical balance. This ADM was crushed with the aid of a Willey mill. Five grams of this powder were used to bromatological analyzes and the other quantity was placed in the oven at $105^{\circ} \mathrm{C}$ for greenhouse dry mass (GDM) determination.

The moisture, crude protein, crude fiber, etheric extract, mineral residue and phosphorus of leaf biomass were performed according to methodologies of the Association of Official Analytical Chemists (1990).

The $\mathrm{N}$ content was performed by the Kjeldahl method. Phosphorus, potassium and sodium contents by spectrophotometry and flame emission photometry were obtained. Others minerals contents were measured by plasma emission spectrophotometry (EMBRAPA, 1999). These elements were analyzes after the nitric-boric 
digestion (Tedesco et al., 1985) using $1 \mathrm{~g}$ of ADM powder and $5 \mathrm{~mL}$ of nitric acid and perchloric acid solution (3:1 v:v). This mixture was incubated for 2 hours at $200{ }^{\circ} \mathrm{C}$.

\subsection{Statistical Analysis of the Indicators of Soil Quality and of Leaf Biomass}

The experiment was in completely randomized block design with factorial unfolding (10 biofertigation managements and three leaf biomass cuttings).

The analysis of variance and Tukey's test at 5\% significance were used to compare the soil physical-chemical indicators and bromatological composition of leaf biomass. The estimate of these parameters were performed at 95\% confidence level, based on the coefficient of variation (CV) limits (Pimentel-Gomes, 2000). This author classifies the experimental variations in low variation $(\mathrm{CV}<10 \%)$, medium $(10<\mathrm{CV}<20 \%)$, high $(20<\mathrm{CV}<$ at $30 \%)$, and very high $(\mathrm{CV}>30 \%)$.

The mathematical models, two-dimensional and multidimensional, were obtained from the adjustment of the points derived from the correlations of the variables, with higher coefficient of explanation $\left(\mathrm{R}^{2}\right)$ and significance.

The graphs to present the relationships between the variables were performed from the spreadsheets/software: Excel, Surfer, SigmaPLOT12.0 and Minitab 17.

\section{Results and Discussions}

\subsection{Wastewater of Slaughterhouse Composition}

The physical-chemical indicators contents of wastewater of the green line are presented in Table 2. These indicators contents were similar to those obtained in effluents of cattle slaughterhouse (Gomes, 2010; Louvet et al., 2013; Maldaner, 2008; Masse et al., 2000; Pacheco \& Yamanaka, 2008).

The wastewater of slaughterhouse had a diversified composition of primary macronutrients (Nitrogen, Phosphorus and Potassium) and secondary macronutrient (e.g. calcium). Thus, the crude wastewater, despite representing an environmental problem, is used as fertilizer (Azevedo, 2007). This use can reduce or eliminate the addition commercial fertilizers in soil (Hespanhol, 2002).

The wastewater of cattle slaughterhouse had high physical-chemical indicators concentrations (Table 2). Therefore, these wastewaters need a treatment before discarding in the soil and/or in water bodies (Scarassati et al., 2003). The treatment of these effluents, after the removal of the solids and fats, was carried out in stabilization ponds (Silveira, 1999).

After treatment, the effluents of the $3^{\text {rd }}$ stabilization pond can be discarded in the water body (Conama, 2005). However, the effluents of our study had a nitrogen content seven times higher than the maximum limit allowed by Conama (Table 2). This high N content may contribute to eutrophication of water bodies (Conley et al., 2009). Thus, the biofertigation with the wastewater of slaughterhouse in the B. brizantha $\mathrm{cv}$. Marandu planting may be an alternative for reducing the nitrogen content and the risk of eutrophication.

Forage grasses, due to accelerated leaf growth rates, require a large nutrient amount (Barbero et al., 2013; Costa et al., 2016). Thus, the use of wastewater of the green line in meeting the demand of these plants is a viable alternative (Silva et al., 2012, 2016). In soils with adequate aeration capacity, because microbial activity, the nitrogen is in the chemical form of nitrate (De Bona, 2008; Rodrigues et al., 2013; Wu et al., 2015). However, in soils with medium to high drainage capacity (e.g. latosol and neosol) the nitrate leaching occurs, leaving the soil poor in nitrogen (De Bona, 2008). These two types of soil is predominant in the Cerrado biome.

In the wastewater of slaughterhouse, the nitrogen is in different chemical forms that increase of retention in the soil and of absorption by the plant (Table 2). Therefore, the amount and chemical form of this macronutrient changers the plant growth and biomass (Rahayu et al., 2005; Reich et al., 2003). Furthermore, a forage crop with high nitrogen availability has a more vigorous root system than a crop deficient in this nutrient, because of elaborated sap accumulation (Brouwer, 1962).

The wastewater of green line had nitrate and nitrite levels (Table 2) that can be nitrogen source for plant and for the microorganisms of the soil. The roots has the potential to absorb nitrate contained in soil with adequate moisture content (Tinker \& Nye, 2000).

The sodium content was lower (Table 2) than at the limit level (40 mg/L), recommended to avoid salinization or sodification of soil and groundwater (Gloaguen et al., 2010; Von Sperling, 2005). Furthermore, this wastewater presented electrical conductivity with low level of soil salinization (Bernardo, 2006). Thus, the use of these wastewaters of green line in biofertigation has little or no potential to cause such environmental damage. 
The wastewater $\mathrm{pH}$ was higher than those values obtained in effluents of green line of a cattle slaughterhouse in the south region of Brazil (Klank, 2011). According to these authors, the $\mathrm{pH}$ of these effluents may vary according to the collection period of the samples. Moreover, the basic $\mathrm{pH}$ of wastewater of green line (Table 2) can contribute to the increase of the cation exchange capacity and together with the limestone increase the $\mathrm{pH}$ of the soil solution. These soil changes may favor the development of forage crops and shows the potential of biofertigation with wastewater of green line.

\subsection{Physical-Chemical Indicators Characterization of Soil}

The $\mathrm{pH}$, base saturation and cation exchange capacity of the first soil samples were used to determine the soil acidity adjustment (Table 3$)$. However, for $\mathrm{pH}$ adjustment only the values obtained in the rhizosphere depths $(0$ to 10 and 10 to $20 \mathrm{~cm}$ ) were used. About $80 \%$ of the mass of the root bulb of $B$. brizantha $\mathrm{cv}$. Marandu is in the depths of up to $20 \mathrm{~cm}$.

Soil samples, at depths up to $20 \mathrm{~cm}$, had lower base saturation and cation exchange capacity (Table 3 ) than the recommended values for Marandu (Malavolta, 1989; Primavesi et al., 2008). Thus, in this study, the soil acidity adjustment using $1.728 \mathrm{t} / \mathrm{h}$ a of dolomitic limestone was made. For addition of limestone up to $20 \mathrm{~cm}$, the depth factor was 1.0.

The $\mathrm{pH}$ and sand had low dispersion in the soil profile $(\mathrm{CV}<10 \%)$. The others soil physical-chemical indicators had average to very high dispersion (Figure 2, Table 3). This high dispersion may be due to soil morphological characteristics, nutrient availability and microbial activity (Rodrigues et al., 2013; Santos et al., 2009).

The $\mathrm{pH}$ in the depth of 0 to $30 \mathrm{~cm}$ did not present a significant difference $(\mathrm{p}<0.05)$ in the blocks, but of 90 to $100 \mathrm{~cm}$ it presented a significant difference when compared to the depths of 0 to 10 and 10 to $20 \mathrm{~cm}$ (Table 3). The Cerrado soils has a low acidity and it can vary depending on the time, geographical position and soil depth (Ronquim, 2010).

In the depth of 20 to $30 \mathrm{~cm}$ (Figure 2C), the physical-chemical indicators concentration was lower than in the others depths (Figures 2A, 2B and 2D). However, this fact may be because a very high variability $(\mathrm{CV}=201.3 \%)$ in the potassium content (Figure 2C, Table 3).

In depth greater than 10-20 cm, a reduction in the ions $(\mathrm{H}+\mathrm{Al})$ concentration was observed. While, the base saturation increased with soil depth (Table 3). The soil of the experimental area was sandy-loam, due to, respectively, high percentage $(>60)$ of sand and medium $(<34)$ concentration of clay in $100 \mathrm{~cm}$ of depth (Embrapa, 2006). Rainfall that it has highest infiltration volume in the effective zone of the roots is high in sandy-loam soil (Ronquim, 2010). Therefore, this volume of infiltration could contributed to leaching of the bases and the increase of the ions $\left(\mathrm{H}^{+}\right.$and $\left.\mathrm{Al}^{+3}\right)$ concentration in the soil (Ronquim, 2010; Roscoe et al., 2006).

The concentration and movement of physical-chemical indicators under natural conditions may limit the use of Cerrado soil for agropastoral activities (Gucker et al., 2009; Malavolta \& Kliemann, 1985). In this study, the use dolomitic limestone and fertilizers contributed to the Marandu production in this soil. Furthermore, the biofertigation in Cerrado soil can contribute to reduce the incorporation of new areas with native vegetation to the agropastoral systems. 
Table 3. Concentration of the physical-chemical indicators in the experimental area before of the planting Brachiaria brizantha cv Marandu

\begin{tabular}{|c|c|c|c|c|c|c|c|c|c|}
\hline \multirow{3}{*}{\multicolumn{2}{|c|}{ Physical-chemical indicators }} & \multicolumn{8}{|c|}{ Soil depth (cm) } \\
\hline & & \multicolumn{2}{|c|}{$0-10$} & \multicolumn{2}{|c|}{$10-20$} & \multicolumn{2}{|c|}{$20-30$} & \multicolumn{2}{|c|}{$90-100$} \\
\hline & & Average \pm Sd & CV (\%) & Average $\pm \mathrm{Sd}$ & CV (\%) & Average \pm Sd & CV (\%) & Average \pm Sd & $\mathrm{CV}(\%)$ \\
\hline $\mathrm{pH}\left(\mathrm{CaCl}_{2}\right)$ & & $4.25 \pm 0.17 \mathrm{a}$ & 4.7 & $4.28 \pm 0.11 \mathrm{a}$ & 3.0 & $4.40 \pm 0.13 \mathrm{ab}$ & 3.6 & $5.23 \pm 0.10 \mathrm{~b}$ & 2.2 \\
\hline Clay & \multirow{3}{*}{$\%$} & $26.63 \pm 3.31 \mathrm{a}$ & 14.9 & $28.63 \pm 3.68 \mathrm{a}$ & 15.4 & $30.00 \pm 2.00 \mathrm{a}$ & 8.0 & $31.25 \pm 2.63 \mathrm{a}$ & 10.1 \\
\hline Sand & & $66.63 \pm 4.00 \mathrm{a}$ & 7.2 & $64.25 \pm 4.35 \mathrm{a}$ & 8.1 & $62.50 \pm 2.41 \mathrm{a}$ & 4.61 & $61.13 \pm 3.01 \mathrm{a}$ & 5.9 \\
\hline Silt & & $6.75 \pm 0.74 \mathrm{a}$ & 13.1 & $7.13 \pm 0.70 \mathrm{a}$ & 11.7 & $7.50 \pm 0.45 \mathrm{a}$ & 7.1 & $7.63 \pm 0.43 \mathrm{a}$ & 6.8 \\
\hline $\mathrm{Ca}$ & \multirow{6}{*}{$\begin{array}{l}\frac{\tilde{g}}{0} \\
\frac{\tilde{0}}{0} \\
\frac{\Xi}{0}\end{array}$} & $0.98 \pm 0.32 \mathrm{a}$ & 39.4 & $0.73 \pm 0.14 \mathrm{a}$ & 23.0 & $0.58 \pm 0.12 \mathrm{a}$ & 25.9 & $0.66 \pm 0.12 \mathrm{a}$ & 21.3 \\
\hline $\mathrm{Mg}$ & & $0.64 \pm 0.22 \mathrm{a}$ & 41.9 & $0.48 \pm 0.10 \mathrm{a}$ & 24.5 & $0.43 \pm 0.09 \mathrm{a}$ & 24.4 & $0.49 \pm 0.09 \mathrm{a}$ & 23.1 \\
\hline $\mathrm{Al}$ & & $0.36 \pm 0.19 \mathrm{a}$ & 64.2 & $0.24 \pm 0.14 \mathrm{a}$ & 70.9 & $0.23 \pm 0.15 \mathrm{a}$ & 81.4 & $0.11 \pm 0.09 \mathrm{a}$ & 100.1 \\
\hline $\mathrm{H}+\mathrm{Al}$ & & $6.56 \pm 2.09 \mathrm{a}$ & 38.1 & $7.08 \pm 0.95 \mathrm{a}$ & 16.1 & $5.79 \pm 1.08 \mathrm{a}$ & 22.4 & $2.38 \pm 0.25 \mathrm{~b}$ & 12.5 \\
\hline $\mathrm{K}$ & & $0.10 \pm 0.08 \mathrm{a}$ & 97.8 & $0.08 \pm 0.07 \mathrm{a}$ & 117.3 & $0.11 \pm 0.19 \mathrm{a}$ & 200.2 & $0.03 \pm 0.02 \mathrm{a}$ & 76.7 \\
\hline CEC & & $8.27 \pm 1.93 \mathrm{a}$ & 27.9 & $8.35 \pm 0.97 \mathrm{a}$ & 14.0 & $6.90 \pm 1.13 \mathrm{a}$ & 19.5 & $3.56 \pm 0.35 \mathrm{~b}$ & 11.8 \\
\hline Organic matter & $\mathrm{g} / \mathrm{dm}^{3}$ & $36.88 \pm 4.57 \mathrm{a}$ & 14.8 & $24.63 \pm 7.62 \mathrm{~b}$ & 37.0 & $21.00 \pm 5.06 \mathrm{~b}$ & 28.8 & $10.25 \pm 1.99 \mathrm{c}$ & 23.2 \\
\hline Base saturation & \multirow{2}{*}{$\%$} & $22.92 \pm 9.68 \mathrm{ab}$ & 50.5 & $15.48 \pm 3.01 \mathrm{a}$ & 23.2 & $16.45 \pm 4.15 \mathrm{a}$ & 30.2 & $33.15 \pm 3.83 \mathrm{~b}$ & 13.8 \\
\hline Al saturation & & $18.97 \pm 11.15 \mathrm{a}$ & 70.3 & $13.77 \pm 7.72 \mathrm{a}$ & 67.1 & $16.99 \pm 11.52 \mathrm{a}$ & 81.1 & $7.94 \pm 6.55 \mathrm{a}$ & 98.6 \\
\hline $\mathrm{Na}$ & \multirow{8}{*}{$\frac{\mathfrak{g}}{0.0}$} & $2.13 \pm 0.30 \mathrm{a}$ & 16.6 & $2.25 \pm 0.39 \mathrm{a}$ & 20.6 & $2.25 \pm 0.39 \mathrm{a}$ & 20.6 & $2.13 \pm 0.30 \mathrm{a}$ & 16.6 \\
\hline $\mathrm{Zn}$ & & $2.05 \pm 0.73 \mathrm{a}$ & 42.5 & $1.30 \pm 0.67 \mathrm{a}$ & 61.8 & $1.19 \pm 0.83 \mathrm{a}$ & 84.0 & $1.46 \pm 0.67 \mathrm{a}$ & 54.9 \\
\hline B & & $0.23 \pm 0.03 \mathrm{a}$ & 16.4 & $0.22 \pm 0.04 \mathrm{a}$ & 21.4 & $0.22 \pm 0.04 \mathrm{a}$ & 23.5 & $0.21 \pm 0.03 \mathrm{a}$ & 20.2 \\
\hline $\mathrm{Cu}$ & & $0.54 \pm 0.42 \mathrm{a}$ & 94.3 & $0.31 \pm 0.12 \mathrm{a}$ & 46.6 & $0.39 \pm 0.22 \mathrm{a}$ & 68.2 & $0.44 \pm 0.27 \mathrm{a}$ & 73.2 \\
\hline $\mathrm{Fe}$ & & $51.25 \pm 8.17 \mathrm{a}$ & 19.1 & $54.18 \pm 6.82 \mathrm{a}$ & 18.1 & $37.94 \pm 6.43 \mathrm{a}$ & 20.3 & $28.51 \pm 1.51 \mathrm{~b}$ & 6.4 \\
\hline $\mathrm{Mn}$ & & $0.95 \pm 0.48 \mathrm{a}$ & 59.8 & $1.00 \pm 0.72 \mathrm{a}$ & 86.5 & $1.14 \pm 0.61 \mathrm{a}$ & 64.1 & $0.41 \pm 0.19 \mathrm{a}$ & 54.1 \\
\hline K & & $38.50 \pm 31.51 \mathrm{a}$ & 97.9 & $29.75 \pm 29.77 \mathrm{a}$ & 119.7 & $43.50 \pm 73.19 \mathrm{a}$ & 201.3 & $12.13 \pm 7.84 \mathrm{a}$ & 77.30 \\
\hline P (Melich) & & $1.14 \pm 0.52 \mathrm{a}$ & 54.8 & $1.03 \pm 0.27 \mathrm{a}$ & 31.6 & $0.83 \pm 0.22 \mathrm{a}$ & 32.2 & $0.99 \pm 0.44 \mathrm{a}$ & 52.9 \\
\hline
\end{tabular}

Note. Sd: standard deviation; CV: coefficient of variation; CEC: cation exchange capacity. 

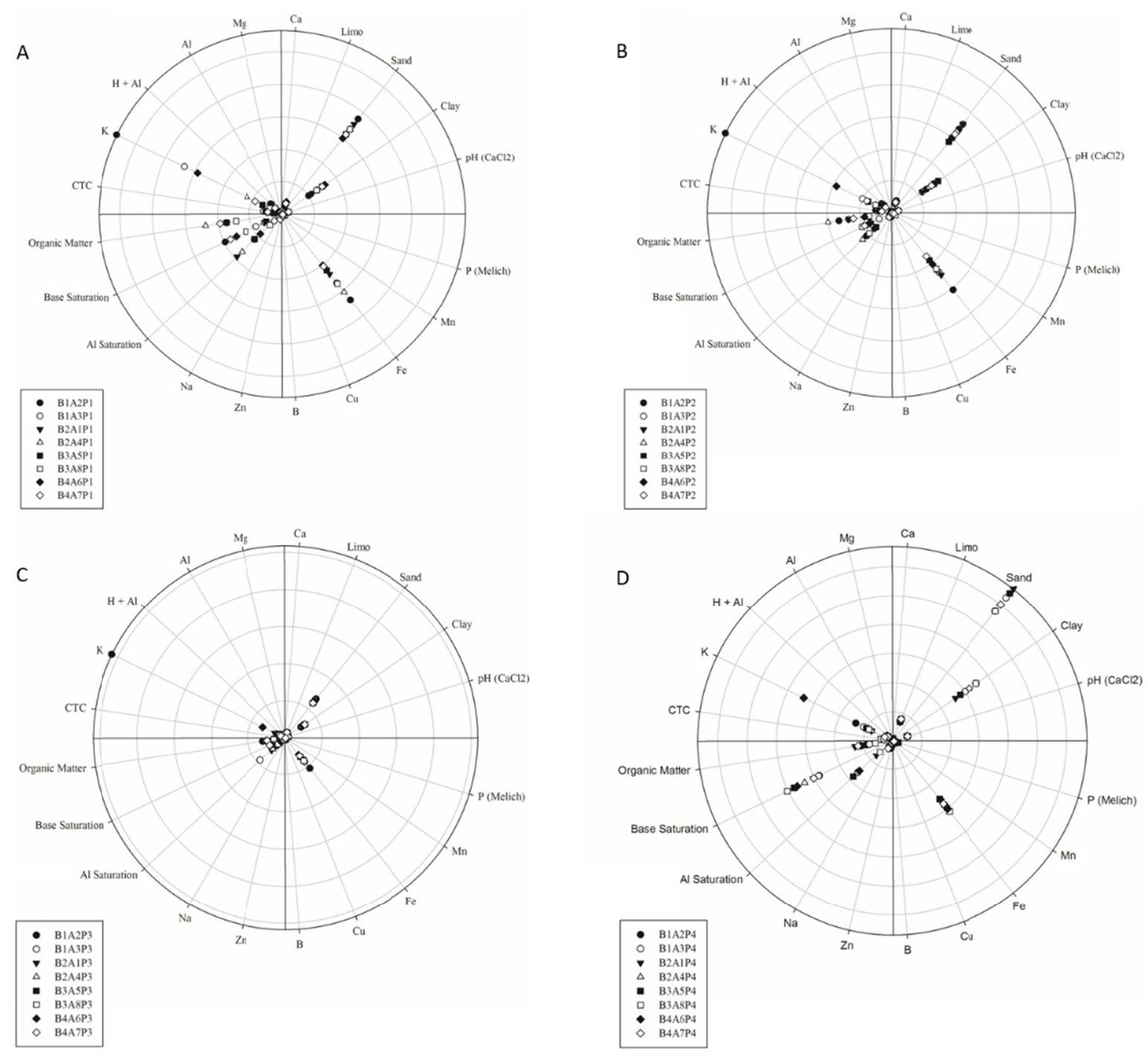

Figure 2. Spatial distribution of the physical-chemical indicators in soil depth of 0 at $10 \mathrm{~cm}(\mathrm{~A}), 10$ at $20 \mathrm{~cm}$ (B), 20 at $30 \mathrm{~cm}$ (C) and 90 at $100 \mathrm{~cm}$ (D) before of the planting Brachiaria brizantha cv Marandu. $\mathrm{B}=$ Experimental block, $\mathrm{A}=$ Sampling point, $\mathrm{P}=$ soil deph

\subsection{Total Soil Water Capacity (TSW) Determination}

The TSW is dependent on the soil morphology and the effective depth of the roots (Cunha et al., 2010; Klar, 1991). The clay, silt and sand amount did not show significant differences $(p<0.05)$ at the sampling points and in the soil depths, but there were significant differences between them (Figure 2, Table 3). Thus, the soil of the experimental area was clay loam with medium texture (Embrapa, 2006).

In this study, the water blade was determined using TSW of $1.2 \mathrm{~mm} / \mathrm{cm}$. In soils of medium texture, this TSW can vary from 0.8 to $1.6 \mathrm{~mm} / \mathrm{cm}$ (Bernardo, 2006).

The effective depth of the roots of $B$. brizantha was $43 \mathrm{~cm}$. The roots depth in the pastures can vary from 30 to $100 \mathrm{~cm}$ (Klar, 1991). Cunha et al (2010) determined roots depth of $43.13 \mathrm{~cm}$ for this forage in cutting management.

The actual soil water capacity (ASW) was $25.8 \mathrm{~mm}$. This value was obtained using TSW of $51.6 \mathrm{~mm}$ and a soil water availability factor of 0.5 . According to Bernardo (2006), this factor for fodder plants varies from 0.3 to 0.7 .

\subsection{Water Demand Determination of Forage}

The mean air temperature, rainfall, potential evapotranspiration and TSW to calculate a climatological water balance for fodder were used (Figure 3). 
The water blade to meet crop demand was applied on soil, due to the scarcity of rainfall in a given period of the year (Figure 3).

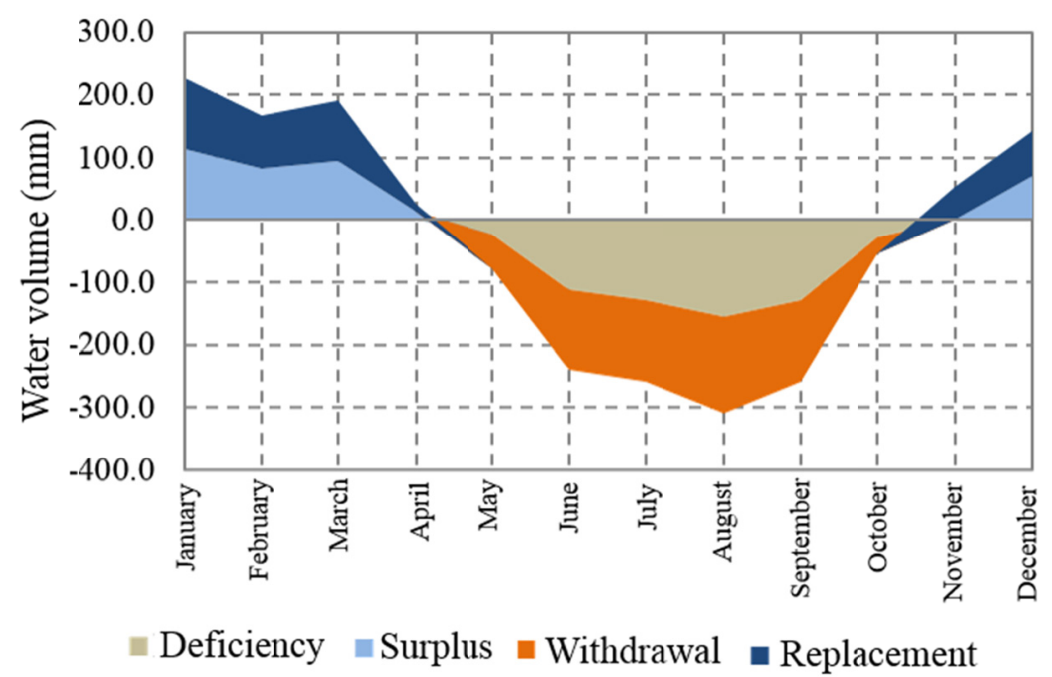

Figure 3. Water availability for Brachiaria brizantha $\mathrm{cv}$. Marandu in biofertigation managements with wastewater of cattle slaughterhouse. This balance was estimated from a historical series from 2001 to 2009 of Palmas, TO, Brazil

\subsection{Management of Biofertigation of B. brizantha cv. Marandu}

\subsubsection{Nutritional Demand of Forage}

This demand for B. brizantha cv Marandu was of 113.745 and $47.357 \mathrm{~kg} / \mathrm{ha}$, respectively, for $\mathrm{P}_{2} \mathrm{O}_{5}$ and $\mathrm{K}_{2} \mathrm{O}$. These concentrations are the minimum limits for pasture (Alcântara, 1999).

The nitrogen content of the soil samples was not used in the nutritional demand, because high volatility, leaching and microbial degradation of the chemical forms of this element (Madigan et al., 2010; Rodrigues et al., 2013). Thus, it was applied in the soil $150.000 \mathrm{~kg} / \mathrm{ha}$ of nitrogen which is the value required by B. brizantha (Freire et al., 2012). This element was obtain of commercial source and wastewater of slaughterhouse (Table 1).

\subsubsection{Demand of Forage Water}

The crop coefficient for $B$. brizantha was of 1.10 . This value was similar to those used in irrigated pasture (Alencar et al., 2009).

In the interval between the pre-planting (06/22/2015) and third grass cutting (03/27/2016), sixty-four applications of water blade in 20 bioferrigation managements were performed during the daytime period. The addition of water layer containing the wastewater of green line was initiated after the $18^{\text {th }}$ application of water blade (08/19/2015). At this date, we observed that the grass had an average height of $20 \mathrm{~cm}$.

\subsection{Parameters Evaluated After Biofertigation Management}

\subsubsection{Characterization of Soil Physic-Chemical Indicators}

The physical-chemical indicator contents did not show significant differences $(\mathrm{p}<0.05)$ in soil depths and biofertigation managements (Figures 4 and 5).

The fine particle of soil has a tendency of leaching, because the water infiltration capacity in the sandy clay loam soil. This soil, the velocity of water infiltration is of $13.6 \pm 0.2 \mathrm{~cm} / \mathrm{h}$ (Carvalho et al., 2015). According to Bernardo (2006), this speed is very high.

The physical-chemical indicators of the soil solution has greater dispersion after the biofertigation than before planting of the forage (Figures 4 and 5, Tables 3). The first samples was collected in the dry season, with a very low water layer in the soil. The soil was concentrated with the few indicators/compounds in solution (Figure 2, Table 3). While, the samples to evaluate the impact of the biofertigation management were collected in the period with soil moisture close to the field capacity. This moisture favored a greatest dispersion of the 
compounds in the soil solution. Furthermore, this dispersion can be enhanced by the heterogeneity of the porous space of the soil, especially the portion relative to the microspores.

The soil physical-chemical indicators contents before soil preparation for planting and after the biofertigation management did not present significant differences (Table 3). According to Koura et al. (2002), the changes in soil chemical characteristics are observed after several years of irrigation with wastewater, because the slow soil dynamics. However, in this study, a decline of these indicators contents with the biofertigation managements was observed (Table 3). This result shows that the sizing of the nutritional demand of the forage with the nutrients availability in the soil was adequate.

In the agropastoral systems, for keep the soil quality and avoid the erosion are necessary adjusts soil acidity every year and increase the nutrients availability in the soil. Furthermore, acidity adjustment and soil fertilization provide an increase in forage accumulation in soil cover and in plant height and reduce the weed percentage (Townsend et al., 2010).

The nutritional demand of $B$. brizantha was also determined by phosphorus content of wastewater and of soil (Tables 2 and 3). The phosphorus have been one of the elements of greatest impact on the limitation of pasture longevity in Cerrado soil (Drudi \& Braga, 1990; Veiga \& Serrão, 1990).
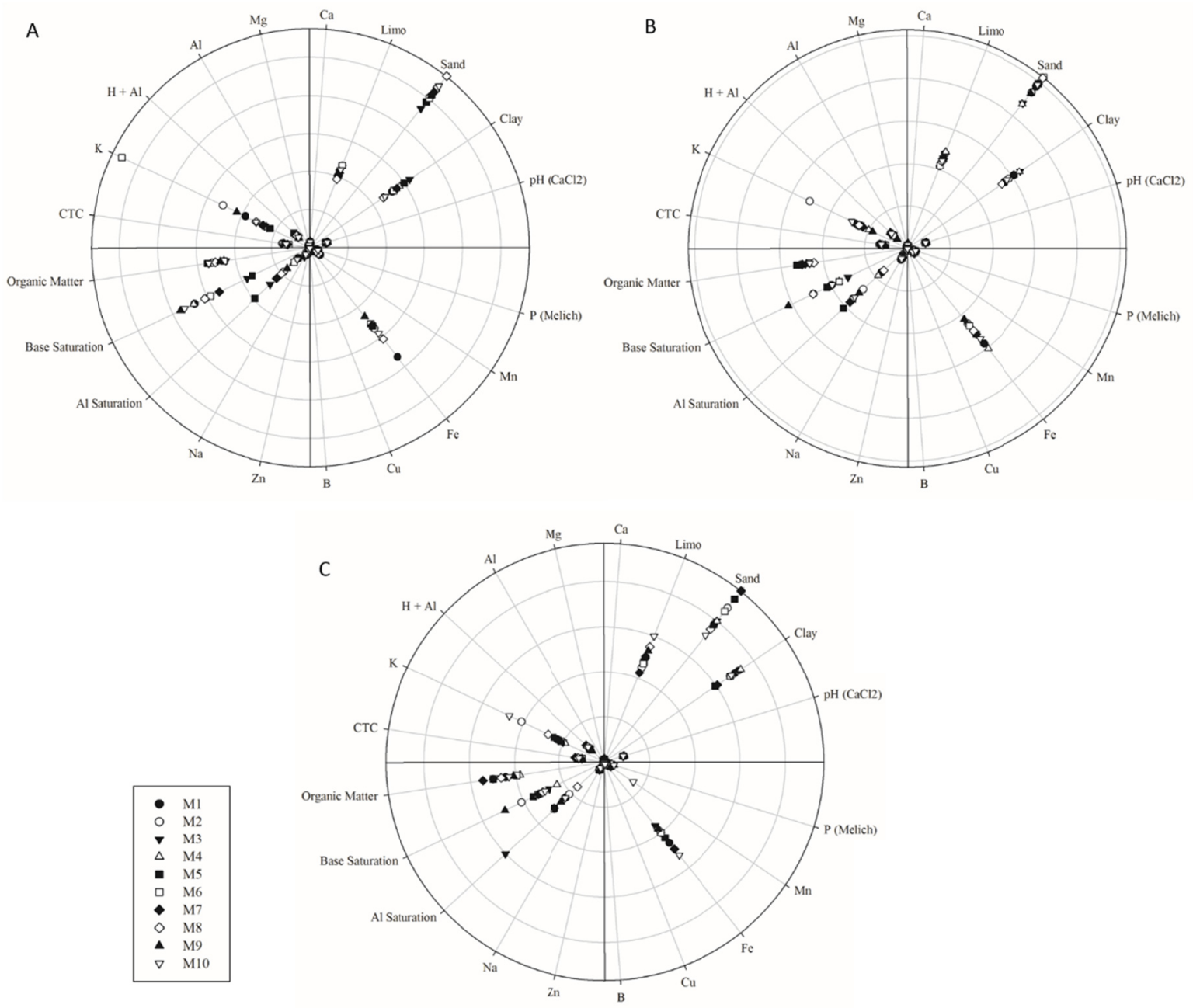

Figure 4. Spatial distribution of the physical-chemical indicators in soil depth of 0 at $10 \mathrm{~cm}$ (A), 10 at $20 \mathrm{~cm}$ (B) and 20 at $30 \mathrm{~cm}$ (C) after in the biofertigation management (M1 to M10) in the planting of Brachiaria brizantha cv Marandu 


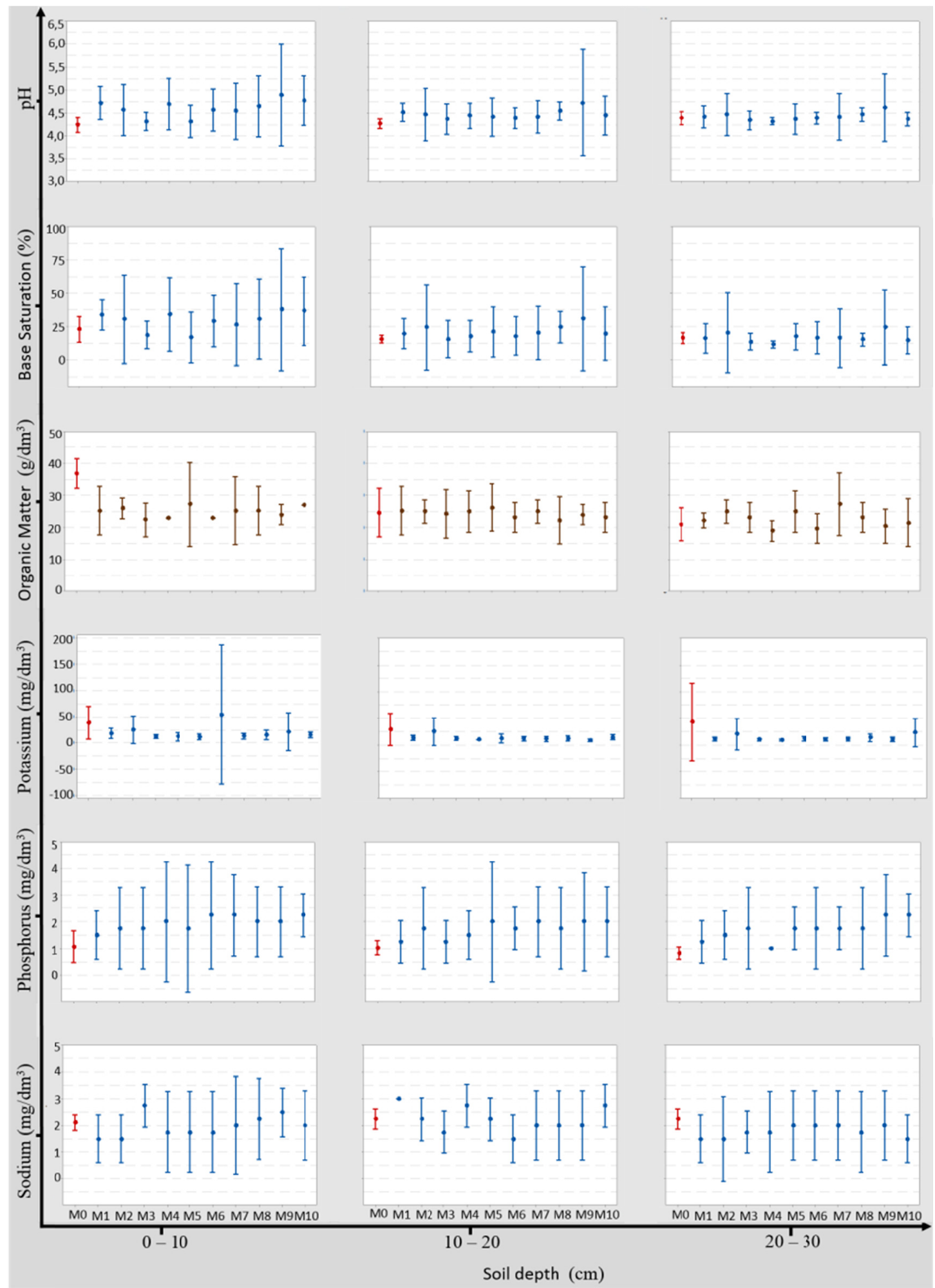

Figure 5. Physical-chemical indicators before soil preparation (M0) and after biofertigation management (M1 to M10) in soil depth of 0 at $10 \mathrm{~cm}, 10$ at $20 \mathrm{~cm}$ and 20 at $30 \mathrm{~cm}$

\subsubsection{Characterization of the Soil Resistance Physical Indicator}

In the biofertigation managements, the $B$. brizantha roots had a high variability in the soil penetration capacity (Figure 6). However, this root penetration does not depend exclusively on depth, since the coefficient of determination $\left(\mathrm{R}^{2}\right)$ was of 0.309 to 0.6849 (Figure 6). These coefficients express a positive interdependence 
between depth and penetration resistance. In addition, this variation indicates that others variables have influence on the root penetration capacity.
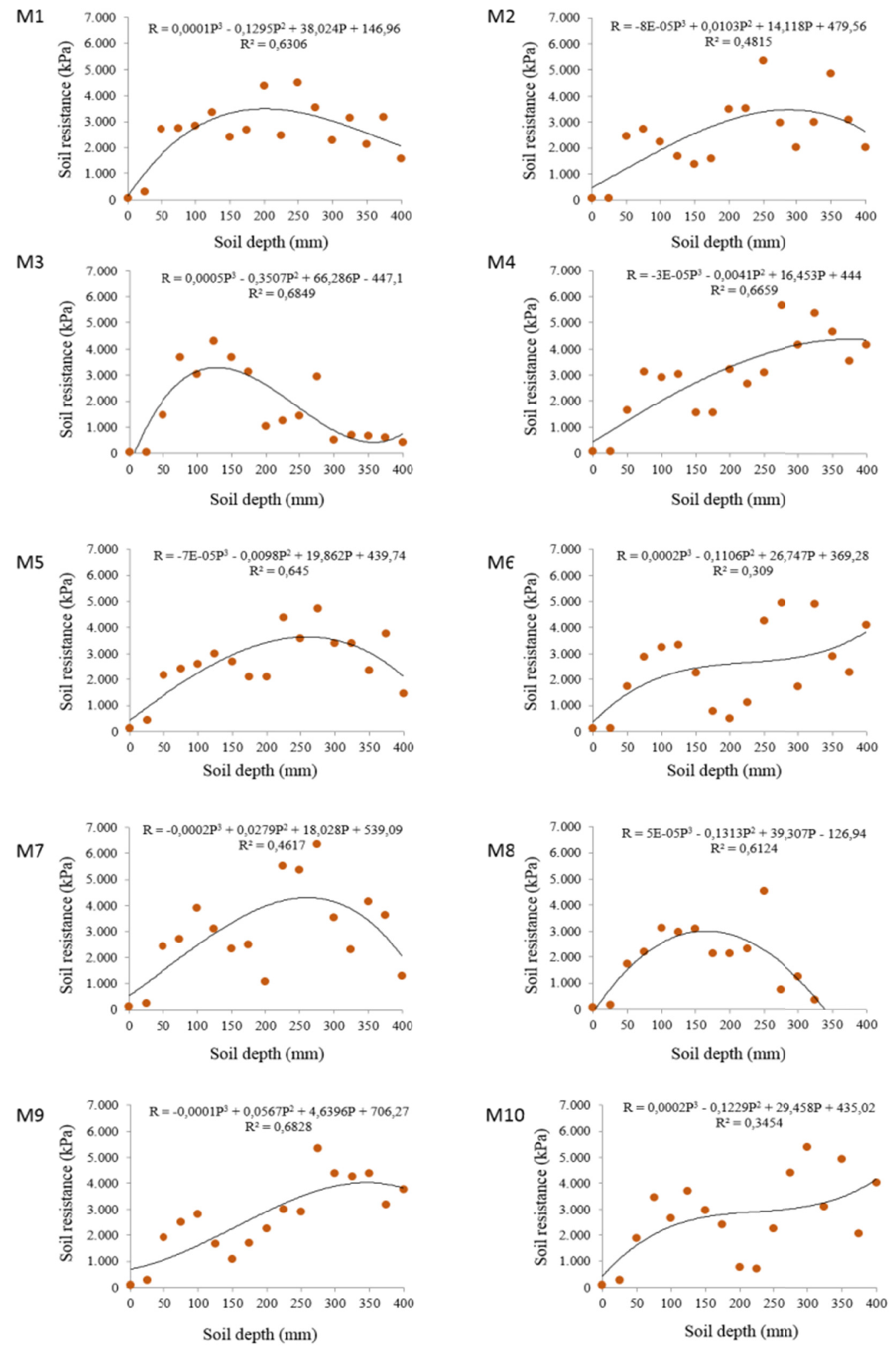

Figure 6. Soil resistance the penetration of roots of Brachiaria brizantha cv. Marandu after biofertigation management (M1 to M10) 
In this study, the root system and soil penetration capacity were directly proportional (Table 4). The root system well developed, gives the plant greatest capacity to withstand stress, such as severe winters, dry summers and grazing (Cunha et al., 2010).

The increase of the wastewater of slaughterhouse doses may be limited the roots growth in resistance tension of 2.5 $\mathrm{MPa}$ (Figure 7, Table 4). However, soil resistance to root penetration between 1.0 and 3.5 MPa restricts root growth (Benghough \& Mullins, 1990). In soils with pasture crops has been indicated a limit of $2.5 \mathrm{MPa}$ (Leão et al., 2004). Furthermore, the plant growth are also limited by morphological characteristics and the water retention capacity of the soil (Lapen et al., 2004; Leão et al., 2004; Tormena et al., 1998).

Mathematical models of the soil resistance determined the relationship between the nitrogen of wastewater and of root depth (Figure 7). These models may aid in the estimation of root depth and of nitrogen dose for be used in planting of B. brizantha. Root depth is fundamental for acidity adjustment, soil fertility and addition of water blade (Doran \& Parkin, 1994; Stenberg, 1999). Furthermore, this depth has a positive influence on leaf growth and biomass production (Stenberg, 1999; Cunha et al., 2010).

The root penetration had a positive correlation with the increase of up to $17.5 \%$ of nitrogen of wastewater of reception box. In the largest doses of this element, the correlation was zero or negative depending on the applied voltage (Figure 7A). This behavior was due to the high fat content that caused an obstruction of the soil porosity (Table 2). The obstruction reduced the capacity of water infiltration and air circulation in the soil. Meanwhile, the root penetration had a positive correlation with depth at doses up to $50 \%$ of nitrogen of wastewater of $3^{\text {rd }}$ stabilization pond (Figure 7B). The application of nitrogen of the manure also showed a positive correlation up to the dose of $20 \%$ and in the largest doses, the vertical root growth showed a negative correlation (Figure 7C). These results show the necessity of the treatment of wastewater of green line for application in the soil. This wastewater when distributed on the soil can form a layer that hinders the penetration of water and compromises the elevation of moisture to the field capacity.

Table 4. Penetration of the roots of Brachiaria brizantha cv. Marandu in differ management of biofertigation (M1 to M10) with wastewater of slaughterhouse

\begin{tabular}{lll}
\hline \multirow{2}{*}{ Biofertigation Management } & \multicolumn{2}{c}{ Soil depth $(\mathrm{cm})$} \\
\cline { 2 - 3 } & $1.5 \mathrm{MPa}$ & $2.5 \mathrm{MPa}$ \\
\hline M1 & 4.1 & 8.9 \\
M2 & 7.1 & 14.5 \\
M3 & 3.6 & 6.4 \\
M4 & 6.6 & 13.4 \\
M5 & 5.6 & 11.6 \\
M6 & 5.3 & 14.1 \\
M7 & 5.1 & 10.5 \\
M8 & 4.9 & 9.7 \\
M9 & 8.9 & 16.1 \\
M10 & 4.4 & 11.5 \\
\hline
\end{tabular}



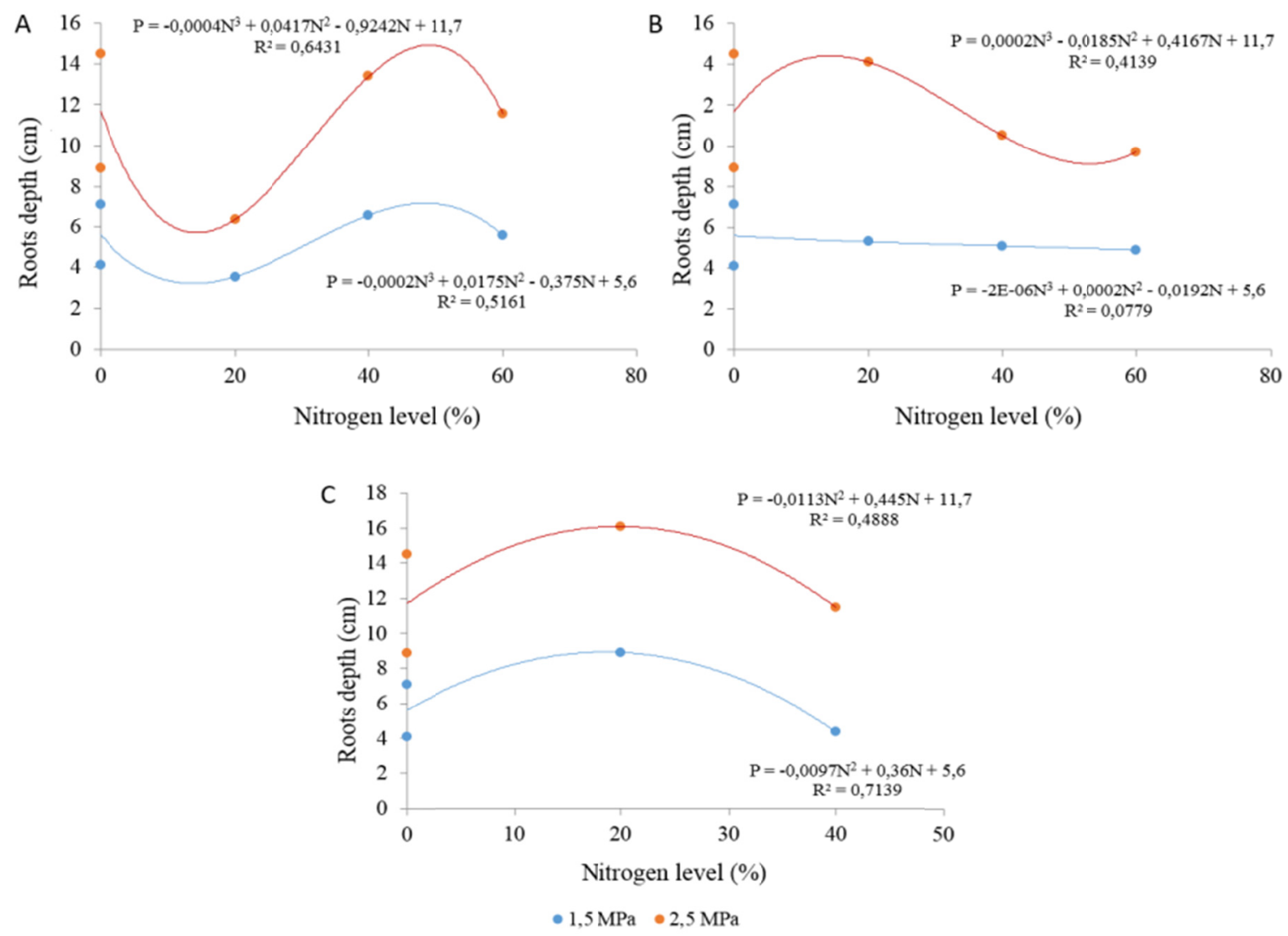

Figure 7. Penetration capacity of the roots of Brachiaria brizantha $\mathrm{cv}$. Marandu by nitrogen level of the reception box (A), $3^{\text {rd }}$ stabilization ponds (B) and manure (C)

\subsection{Characterization of Leaf Biomass}

The first cutting of leaf biomass was performed in 11/30/2015, after 160 days of the planting of the grass (Table 5). Regardless of biofertigation management, the seedlings took about a month. Silva (2017) also observed similar to time for seedling formation of B. brizantha cv. Marandu in Cerrado soil with or without added of wastewater. This long time may also have due to low rainfall during in planting of seed (Figure 3).

The second and third cuttings were made, respectively, after 49 and 71 days do first cutting (Table 5). These cuttings time were similar to the Silva (2017) in fertigation of Marandu with domestic wastewater.

Leaf biomass productivity in the first cutting was low in the management without or with wastewater (Table 5). This productivity showed of high to very high variability (Table 5). The low productivity in this cutting may be due to the plant not having completed its cycle of leaf development. With the exception of the plants of the managements M9 and M10, the others plants had a low soil cover in this cutting. In these managements (M9 and M10), the layer formed in the soil by the manure may have contributed to a reduction of the soil temperature that improved the humidity conditions and the cation exchange. In addition, the managements M1 to M9 showed not difference in dry mass productivity, but the M10 had a significant difference $(\mathrm{p}<0.05)$ in relation to the M2 and M8 (Table 5).

In the second cutting, the leaf biomass productivity showed high to very high variability and did not have significant differences $(\mathrm{p}<0.05)$ between the biofertigation managements. In addition, the parcels with wastewater had higher biomass productivity than the others (Table 5). These results show that, at this stage, the biofertigation contributed to the forage growth. 
Table 5. Leaf biomass after management of biofertigation (M1 to M10). The cuttings were made after 160, 209 and 280 days after planting Brachiaria brizantha cv Marandu.

\begin{tabular}{|c|c|c|c|c|c|c|}
\hline \multirow{2}{*}{$\begin{array}{l}\text { Biofertigation } \\
\text { managements }\end{array}$} & \multicolumn{2}{|c|}{ Organic matter } & \multicolumn{2}{|c|}{ Mineral mass } & \multicolumn{2}{|l|}{ Dry mass } \\
\hline & Average \pm Sd & $\mathbf{C V}$ & Average \pm Sd & $\mathrm{CV}$ & Average \pm Sd & $\mathbf{C V}$ \\
\hline & 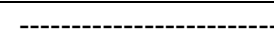 & & --------- kg/ha & 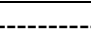 & 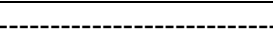 & ------. \\
\hline \multicolumn{7}{|l|}{$1^{\text {nd }}$ cutting } \\
\hline M1 & $345.7 \pm 638.8 \mathrm{ab}$ & 116.1 & $25.5 \pm 51.9 \mathrm{ab}$ & 127.7 & $371.3 \pm 690.7 \mathrm{ab}$ & 116.9 \\
\hline M2 & $237.1 \pm 273.0 \mathrm{a}$ & 72.35 & $13.2 \pm 17.8 \mathrm{ab}$ & 84.5 & $250.3 \pm 288.1 \mathrm{a}$ & 72.3 \\
\hline M3 & $72.9 \pm 86.2 \mathrm{a}$ & 74.3 & $3.9 \pm 5.2 \mathrm{a}$ & 84.2 & $76.8 \pm 91.4 \mathrm{a}$ & 74.8 \\
\hline M4 & $318.3 \pm 384.9 \mathrm{a}$ & 76.0 & $27.1 \pm 35.7 \mathrm{ab}$ & 82.9 & $345.4 \pm 420.5 \mathrm{a}$ & 76.5 \\
\hline M5 & $348.2 \pm 239.1 \mathrm{a}$ & 43.1 & $22.1 \pm 19.1 \mathrm{ab}$ & 54.1 & $370.4 \pm 251.1 \mathrm{a}$ & 42.6 \\
\hline M6 & $263.4 \pm 125.3 \mathrm{a}$ & 29.9 & $22.4 \pm 12.7 \mathrm{~b}$ & 35.6 & $285.8 \pm 126.1 \mathrm{a}$ & 27.73 \\
\hline M7 & $181.6 \pm 314.8 \mathrm{a}$ & 109.0 & $12.4 \pm 21.4 \mathrm{ab}$ & 108.6 & $193.9 \pm 336.2 \mathrm{a}$ & 108.9 \\
\hline M8 & $190.0 \pm 296.4 \mathrm{a}$ & 98.1 & $12.3 \pm 26.9 \mathrm{ab}$ & 138.0 & $202.2 \pm 323.1 \mathrm{a}$ & 100.4 \\
\hline M9 & $871.9 \pm 993.5 \mathrm{ab}$ & 71.6 & $64.1 \pm 79.2 \mathrm{ab}$ & 77.7 & $936.0 \pm 1.072 .1 \mathrm{ab}$ & 72.0 \\
\hline M10 & $1.351 .5 \pm 575.3 \mathrm{~b}$ & 17.1 & $62.7 \pm 87.3 \mathrm{ab}$ & 56.0 & $1.414 .2 \pm 570.7 \mathrm{~b}$ & 16.2 \\
\hline \multicolumn{7}{|l|}{$2^{\text {nd }}$ cutting } \\
\hline M1 & $592.1 \pm 689.2 \mathrm{ab}$ & 73.2 & $38.6 \pm 37.7 \mathrm{a}$ & 61.3 & $630.7 \pm 725.4 \mathrm{a}$ & 72.3 \\
\hline M2 & $780.1 \pm 975.0 \mathrm{ab}$ & 78.6 & $40.3 \pm 52.3 \mathrm{a}$ & 81.6 & $820.4 \pm 1.023 .4 \mathrm{ab}$ & 78.4 \\
\hline M3 & $432.9 \pm 264.2 \mathrm{a}$ & 38.4 & $38.1 \pm 28.8 \mathrm{a}$ & 47.4 & $471.0 \pm 292.9 \mathrm{a}$ & 39.1 \\
\hline M4 & $1.834 .4 \pm 2.209 .8 \mathrm{abc}$ & 75.7 & $80.0 \pm 68.6 \mathrm{a}$ & 53.9 & $1.914 .4 \pm 2.271 .9 \mathrm{abc}$ & 74.6 \\
\hline M5 & $2.258 .1 \pm 1.725 .1 \mathrm{abc}$ & 48.0 & $129.5 \pm 105.8 \mathrm{a}$ & 51.4 & $2.387 .6 \pm 1.822 .4 \mathrm{abc}$ & 48.0 \\
\hline M6 & $1.468 .0 \pm 916.0 \mathrm{abc}$ & 39.2 & $107.9 \pm 70.7 \mathrm{a}$ & 41.2 & $1.575 .9 \pm 982.6 \mathrm{abc}$ & 39.2 \\
\hline M7 & $720.9 \pm 1.019 .5 \mathrm{ab}$ & 88.9 & $66.0 \pm 90.0 \mathrm{a}$ & 85.7 & $787.0 \pm 1.068 .2 \mathrm{ab}$ & 85.3 \\
\hline M8 & $1.103 .0 \pm 1.074 .6 \mathrm{ab}$ & 6.2 & $77.1 \pm 75.0 \mathrm{a}$ & 61.2 & $1.180 .0 \pm 1.141 .9 \mathrm{ab}$ & 60.8 \\
\hline M9 & $3.411 .9 \pm 1.997 .8 \mathrm{bc}$ & 36.8 & $174.7 \pm 136.9 \mathrm{a}$ & 49.3 & $3.586 .6 \pm 2.103 .8 \mathrm{bc}$ & 36.9 \\
\hline M10 & $3.562 .8 \pm 1.197 .1 \mathrm{bc}$ & 21.1 & $156.2 \pm 127.3 \mathrm{a}$ & 51.2 & $3.718 .9 \pm 1.290 .5 \mathrm{c}$ & 21.8 \\
\hline \multicolumn{7}{|l|}{$3^{\text {rd }}$ cutting } \\
\hline M1 & $620.4 \pm 545.0 \mathrm{a}$ & 55.2 & $53.9 \pm 54.7 \mathrm{a}$ & 63.8 & $674.3 \pm 598.1 \mathrm{a}$ & 55.7 \\
\hline M2 & $926.9 \pm 920.9 \mathrm{a}$ & 62.4 & $93.7 \pm 96.0 \mathrm{a}$ & 64.4 & $1.020 .6 \pm 1.015 .4 \mathrm{a}$ & 62.5 \\
\hline M3 & $762.0 \pm 817.1 \mathrm{a}$ & 43.1 & $60.7 \pm 82.9 \mathrm{a}$ & 54.8 & $822.8 \pm 899.8 \mathrm{a}$ & 43.9 \\
\hline M4 & $1.779 .1 \pm 2.643 .3 \mathrm{a}$ & 59.7 & $134.7 \pm 166.6 \mathrm{a}$ & 49.7 & $1.913 .8 \pm 2.809 .1 \mathrm{a}$ & 59.0 \\
\hline M5 & $2.077 .7 \pm 1.522 .7 \mathrm{a}$ & 46.1 & $158.3 \pm 133.7 \mathrm{a}$ & 53.1 & $2.236 .0 \pm 1.649 .6 \mathrm{a}$ & 46.4 \\
\hline M6 & $1.428 .0 \pm 931.5 \mathrm{a}$ & 41.0 & $102.6 \pm 43.9 \mathrm{a}$ & 26.9 & $1.530 .6 \pm 955.0 \mathrm{a}$ & 39.2 \\
\hline M7 & $1.789 .5 \pm 651.3 \mathrm{a}$ & 22.9 & $146.0 \pm 85.0 \mathrm{a}$ & 36.6 & $1.935 .5 \pm 727.2 \mathrm{a}$ & 23.6 \\
\hline M8 & $1.335 .5 \pm 454.9 \mathrm{a}$ & 21.4 & $112.2 \pm 29.6 \mathrm{a}$ & 16.6 & $1.447 .7 \pm 471.1 \mathrm{a}$ & 20.5 \\
\hline M9 & $1.892 .8 \pm 1.740 .4 \mathrm{a}$ & 36.9 & $103.5 \pm 31.1 \mathrm{a}$ & 12.1 & $1.996 .3 \pm 1.731 .6 \mathrm{a}$ & 34.8 \\
\hline M10 & $1.572 .4 \pm 560.7 \mathrm{a}$ & 22.4 & $88.2 \pm 82.1 \mathrm{a}$ & 58.5 & $1.660 .6 \pm 639.5 \mathrm{a}$ & 24.2 \\
\hline
\end{tabular}

Note. $\mathrm{CV}=$ coefficient of variation (\%).

Similar to the $2^{\text {nd }}$ cutting, the biomass productivity in the $3^{\text {rd }}$ cutting also showed high to very high variability and did not have significant differences $(\mathrm{p}<0.05)$ in the biofertigation managements (Table 5).

A linear increase in biomass productivity by nitrogen dose was observed in the managements with wastewater of $3^{\text {rd }}$ stabilization (Table 5). Meanwhile, in managements with wastewater of reception box (untreated) and manure showed an increase in biomass productivity, respectively, in $40 \%$ and $20 \%$ of nitrogen (Table 5). These results confirm the need to treat the effluents for application in biofertigation and shows the importance of the casualization of the experiment. Silva (2017) also observed the importance of the casualization of managements with domestic wastewater applied to the Marandu grass fertigation. This author showed that the dry mass productivity depends of dose and the cutoff period. Our results also show a proportional increase of the biomass productivity by cutting. 
Leal biomass productivity by commercial nitrogen $\left(\mathrm{N}_{\text {com }}\right)$ and nitrogen of the green line wastewater $\left(\mathrm{N}_{\mathrm{bio}}\right)$ was determined by multivariate mathematical model (Table 6).

The biomass productivity was best represented by mathematical models of the $3^{\text {rd }}$ cutting. These results may be because better stage of plant growth (Table 6).

The marginal rate of productivity had value of $16.5,9.3$ and 14.4 ( $\mathrm{kg} / \mathrm{dry}$ mass), respectively, for the $\mathrm{N}_{\text {bio }}$ of $3^{\text {rd }}$ stabilization pond, reception box and manure (Table 6). Therefore, the treated wastewater provided a greatest productivity per unit area and a highest use in water volume. Furthermore, in the $3^{\text {rd }}$ cutting, a positive correlation was observed between the dry mass productivity and the $\mathrm{N}_{\text {com }}$ and $\mathrm{N}_{\text {bio }}$ doses with explanation coefficient $\left(\mathrm{R}^{2}\right)$ of 30 at $70.32 \%$.

The $\mathrm{N}_{\text {com }}$ and $\mathrm{N}_{\text {bio }}$ of $3^{\text {rd }}$ stabilization pond has negative effect (Table 6). This result may be due to the microbial activity. The soil microorganisms are part of the biogeochemical cycle of the nitrogen performing the fixation, nitrification and denitrification and provides sources of this nutrient for the plants (Madigan et al., 2010; Rodrigues et al., 2013; Wu et al., 2015). Moreover, this microbiota is responsible for the cycling of nutrients and energy flow in the soil (Moreira \& Siqueira, 2006). Our research group is investigating the impacts of biofertigation management with wastewater of the green line on the soil microbiota (Carvalho et al., 2018).

Table 6. Multivariate mathematical model of the dry mass $(\mathrm{kg} / \mathrm{ha})$ by commercial nitrogen $\left(\mathrm{N}_{\mathrm{com}}\right)$ and wastewater nitrogen $\left(\mathrm{N}_{\mathrm{bio}}\right.$ ). The $\mathrm{N}_{\mathrm{bio}}$ was obtained of wastewater of the green line

\begin{tabular}{|c|c|c|c|}
\hline Wastewater of the green line & Biomass cutting & Multivariate mathematical model & $\mathbf{R}^{2}$ \\
\hline \multirow[t]{3}{*}{$3^{\text {rd }}$ stabilization pond } & $1^{\text {nd }}$ & $\mathrm{DM}=371.2700-1.3659 \cdot \mathrm{N}_{\mathrm{com}}+0.7302 \cdot \mathrm{N}_{\text {bio }}$ & 0.4696 \\
\hline & $2^{\text {nd }}$ & $\mathrm{DM}=630.7132-1.0274 \cdot \mathrm{N}_{\mathrm{com}}+19.4560 \cdot \mathrm{N}_{\text {bio }}$ & 0.8107 \\
\hline & $3^{\text {rd }}$ & $\mathrm{DM}=674.2513-0.7564 \cdot \mathrm{N}_{\mathrm{com}}+16.5475 \cdot \mathrm{N}_{\text {bio }}$ & 0.8564 \\
\hline \multirow[t]{3}{*}{ Reception box } & $1^{\text {nd }}$ & $\mathrm{DM}=371.2700-0.6853 \cdot \mathrm{N}_{\mathrm{com}}-1.4724 \cdot \mathrm{N}_{\text {bio }}$ & 0.8672 \\
\hline & $2^{\text {nd }}$ & $\mathrm{DM}=630.7132+2.7773 \cdot \mathrm{N}_{\mathrm{com}}+3.7441 \cdot \mathrm{N}_{\text {bio }}$ & 0.3002 \\
\hline & $3^{\text {rd }}$ & $\mathrm{DM}=674.2513+3.7095 \cdot \mathrm{N}_{\mathrm{com}}+9.3305 \cdot \mathrm{N}_{\mathrm{bio}}$ & 0.7042 \\
\hline \multirow[t]{3}{*}{ Manure } & $1^{\text {nd }}$ & $\mathrm{DM}=371.2700-0.5759 \cdot \mathrm{N}_{\mathrm{com}}+18.8220 \cdot \mathrm{N}_{\text {bio }}$ & 0.9917 \\
\hline & $2^{\text {nd }}$ & $\mathrm{DM}=630.7132+4.1910 \cdot \mathrm{N}_{\mathrm{com}}+52.2001 \cdot \mathrm{N}_{\mathrm{bio}}$ & 0.8655 \\
\hline & $3^{\text {rd }}$ & $\mathrm{DM}=674.2513+3.7661 \cdot \mathrm{N}_{\mathrm{com}}+14.4319 \cdot \mathrm{N}_{\mathrm{bio}}$ & 0.7343 \\
\hline
\end{tabular}

Note. DM = Dry mass.

The leaf biomass productivity in the third cutting were obtained after 71 days of plant growth. This time represents approximately 0.1945 days of the year. Thus, under same growing conditions, this annual production could be 5.14 times highest. This shows the potential of biofertigation with treated wastewater/manure from the cattle slaughterhouse for irrigation of $B$. brizantha cv. Marandu on Cerrado soil. The soil of this biome presents low water and nutrients availability (Gucker et al., 2009). The potential of wastewater for irrigation of agricultural crops has been observed in other studies (Biswas et al., 2015; Malafaia et al., 2016; Silva et al., 2016, Silva, 2017).

\subsubsection{Bromatological Analysis of Leaf Biomass}

The crude protein, elements (e.g. N, P, K, S, and Fe), crude fiber, etheric extract, and total digestive nutrients contents was difference $(\mathrm{p}<0.05)$ between cuttings (Table 7). An increase in $\mathrm{Ca}$ and $\mathrm{Zn}$ contents and a reduction of the nitrogen and iron levels was also observed in the cuttings (Table 7). Silva (2017) showed that bromatological composition of the Marandu grass is depend of the cutting period. 
Table 7. Bromatological composition of the leaf biomass of roots of Brachiaria brizantha cv. Marandu after biofertigation managements (see Table 1)

\begin{tabular}{|c|c|c|c|c|c|c|c|c|}
\hline \multirow{3}{*}{$\begin{array}{l}\text { Bromatologica } \\
\text { composition }\end{array}$} & & \multirow{3}{*}{$\begin{array}{l}\text { Biofertigation } \\
\text { management }\end{array}$} & \multicolumn{6}{|c|}{ Leaf biomass cuttings } \\
\hline & & & \multicolumn{2}{|c|}{ First } & \multicolumn{2}{|c|}{ Second } & \multicolumn{2}{|c|}{ Third } \\
\hline & & & Average & CV (\%) & Average & CV (\%) & Average & CV $(\%)$ \\
\hline \multirow{10}{*}{\multicolumn{2}{|c|}{$\mathrm{N}$}} & M1 & 32.00 & 28.53 & 22.38 & 23.89 & 15.75 & 9.52 \\
\hline & & M2 & 35.00 & 12.99 & 25.13 & 18.05 & 15.25 & 6.28 \\
\hline & & M3 & 35.75 & 4.78 & 27.80 & 9.67 & 15.50 & 4.56 \\
\hline & & M4 & 32.38 & 13.19 & 24.00 & 24.77 & 14.67 & 3.94 \\
\hline & & M5 & 30.75 & 12.28 & 22.50 & 16.43 & 16.00 & 7.22 \\
\hline & & M6 & 33.50 & 6.79 & 23.00 & 16.27 & 16.00 & 5.10 \\
\hline & & M7 & 33.75 & 11.44 & 25.38 & 18.58 & 15.50 & 6.45 \\
\hline & & M8 & 32.75 & 10.09 & 25.75 & 21.12 & 15.25 & 3.28 \\
\hline & & M9 & 25.13 & 4.10 & 18.88 & 3.33 & 14.67 & 10.41 \\
\hline & & M10 & 24.00 & 14.93 & 20.75 & 7.49 & 14.50 & 3.98 \\
\hline $\mathrm{P}$ & \multirow{14}{*}{$\mathrm{g} / \mathrm{kg}$} & & 1.26 & 11.91 & 1.36 & 9.17 & 1.60 & 17.05 \\
\hline $\mathrm{K}$ & & M1M10* & 17.17 & 12.77 & 14.05 & 13.55 & 24.08 & 31.33 \\
\hline $\mathrm{Ca}$ & & М1-Мा0* & 2.15 & 8.71 & 2.17 & 8.36 & 4.05 & 33.15 \\
\hline $\mathrm{Mg}$ & & & 2.08 & 15.20 & 2.49 & 17.61 & 3.28 & 30.28 \\
\hline \multirow{10}{*}{$\mathrm{S}$} & & M1 & 1.85 & 23.97 & 1.48 & 6.49 & 0.33 & 15.38 \\
\hline & & M2 & 2.10 & 24.59 & 1.73 & 5.55 & 0.40 & 20.41 \\
\hline & & M3 & 2.08 & 14.39 & 1.85 & 3.12 & 0.50 & 56.57 \\
\hline & & M4 & 1.93 & 11.52 & 1.60 & 5.10 & 0.53 & 43.30 \\
\hline & & M5 & 2.28 & 17.72 & 1.70 & 4.80 & 0.50 & 16.33 \\
\hline & & M6 & 2.50 & 10.33 & 1.70 & 8.32 & 0.43 & 22.53 \\
\hline & & M7 & 1.93 & 17.16 & 1.63 & 3.08 & 0.38 & 45.54 \\
\hline & & M8 & 1.83 & 14.41 & 1.78 & 7.09 & 0.43 & 44.54 \\
\hline & & M9 & 2.03 & 19.91 & 1.60 & 7.22 & 0.50 & 0.00 \\
\hline & & M10 & 2.15 & 30.02 & 1.73 & 5.55 & 0.53 & 28.57 \\
\hline $\mathrm{Zn}$ & & \multirow{7}{*}{ M1-M10* } & 29.87 & 13.15 & 31.57 & 13.18 & 41.90 & 47.31 \\
\hline $\mathrm{Cu}$ & & & 6.90 & 18.11 & 7.12 & 11.20 & 6.96 & 17.57 \\
\hline $\mathrm{Mn}$ & & & 63.25 & 24.71 & 58.77 & 27.46 & 59.35 & 18.76 \\
\hline $\mathrm{Na}$ & & & 116.62 & 11.14 & 116.60 & 7.69 & & \\
\hline $\mathrm{Co}$ & & & 0.16 & 8.62 & 0.18 & 10.12 & 0.34 & 38.84 \\
\hline Mo & & & 0.56 & 7.73 & 0.56 & 5.99 & 0.36 & 26.81 \\
\hline B & & & 24.02 & 15.27 & 23.45 & 20.69 & & \\
\hline \multirow{10}{*}{\multicolumn{2}{|c|}{$\mathrm{mg} / \mathrm{kg}$}} & M1 & 1791.75 & 12.80 & 1485.25 & 30.14 & 442.75 & 43.21 \\
\hline & & M2 & 1553.75 & 38.14 & 1131.75 & 21.40 & 876.00 & 27.44 \\
\hline & & M3 & 1453.00 & 25.52 & 1740.00 & 26.89 & 706.50 & 7.31 \\
\hline & & M4 & 1303.50 & 34.80 & 1344.50 & 49.56 & 641.33 & 10.32 \\
\hline & & M5 & 1477.50 & 16.94 & 1139.00 & 35.08 & 581.50 & 36.52 \\
\hline & & M6 & 2695.00 & 41.53 & 1721.25 & 14.95 & 678.75 & 24.79 \\
\hline & & M7 & 1390.25 & 25.44 & 1862.50 & 37.94 & 560.50 & 20.63 \\
\hline & & M8 & 2010.00 & 26.26 & 2087.00 & 39.29 & 410.25 & 34.88 \\
\hline & & M9 & 1130.00 & 25.96 & 485.50 & 37.35 & 720.33 & 32.05 \\
\hline & & M10 & 782.25 & 68.57 & 383.75 & 39.04 & 494.00 & 37.89 \\
\hline $\mathrm{CP}$ & \multirow{4}{*}{$\%$} & \multirow{4}{*}{ M1-M10* } & 13.25 & 19.38 & 9.95 & 11.87 & 9.70 & 5.75 \\
\hline $\mathrm{CF}$ & & & 21.05 & 6.79 & 22.17 & 5.63 & 24.02 & 3.11 \\
\hline $\mathrm{EE}$ & & & 1.92 & 13.99 & 1.99 & 7.83 & 1.96 & 6.39 \\
\hline TDN & & & 68.45 & 2.22 & 66.73 & 1.46 & 67.05 & 0.95 \\
\hline
\end{tabular}

Note. $\mathrm{CP}=$ crude protein. $\mathrm{CF}=$ crude fiber. $\mathrm{EE}=$ etheric extract. $\mathrm{TDN}$ - total digestive nutrients.

* There was no significant difference $(p<0.05)$ between the biofertigation managements. 
The nitrogen, sulfur and iron contents was difference $(\mathrm{p}<0.05)$ between the biofertigation managements (Table 7). In the managements with manure, the nitrogen and iron concentrations were lower than in the controls. The sulfur concentration varied between the managements.

Thus, the wastewater/manure of the green line of a slaughterhouse and cuttings did not negatively affect the nutritional quality of the B. brizantha cv. Marandu biomass.

\section{Conclusions}

The wastewater of green line from cattle slaughterhouse have potential for use in the irrigation of B. brizantha cv. Marandu. This biofertigation in the Cerrado soil, of medium to long term, provides a mitigation of the leaching of fine particles of soil and cations. The maximum dose of nitrogen of the wastewater/manure meet the maximum demand of this nutrient. The nitrogen of treated wastewater provided a greatest leaf biomass productivity per unit area and a highest use in volume than the commercial nitrogen. In addition, biofertigation can provide a reduction in water demand of water bodies.

\section{Acknowledgements}

The authors are grateful for the financial, scientific and structural support of CAPES, CNPQ, IFTO, BIONORTE, CEULP/ULBRA, UFV and UFT.

\section{References}

Alcântara, P. B. (1999). Forage plants: Grasses \& legumes. São Paulo: Nobel.

Alencar, C. A., Cunha, F. F., Martins, C. E., Cóser, A. C., Wadson Rocha, S. D., \& Araújo, R. A. S. (2009). Pasture irrigation: Present and recommendations for use and management. Brazilian Journal of Animal Science, 38, 98-108. https://doi.org/10.1590/S1516-35982009001300012

Andrade, R. O. B. (2002). Environmental management. Strategic Approach Applied to Sustainable Development $\left(2^{\text {nd }}\right.$ ed.). Pearson Makron Books, São Paulo.

AOAC (Association of Official Analytical Chemists). (1990). Official methods of analysis (15 ${ }^{\text {th }}$ ed.). Washington: AOAC.

APHA (American Public Health Association). (2005). Standard Methods for the Examination of Water and Wastewater (21st ed.). American Water Works Association (AWWA); Water Environment Federation (WEF).

Azevedo, M. R. Q. A., Konig, A., Beltrão, N. E. M., Azevedo, C. A. V., Tavares, T. L., \& Soares, F. A. L. (2007). Effect of irrigation with treated wastewater on production of forage corn. Brazilian Journal of Agricultural Sciences, 2(1), 63-68. Retrieved from http://www.agraria.pro.br/ojs-2.4.6/index.php?journal=agraria\&page= article\&op=view\&path $\% 5 \mathrm{~B} \% 5 \mathrm{D}=392$

Barbero, L. M., Prado, T. F., Basso, K. C., Lima, L. A., Motta, K. M., Krüger, B. C., ... da Silva, G. A. S. (2013). Growth analysis for forage plants applied to the management of pastagens. Veterinary News, 19(2). Retrieved from http://www.seer.ufu.br/index.php/vetnot/article/view/23542

Benghough, A. G., \& Mullins, C. E. (1990). Mechanical impedance to root growth: A review of experimental techniques and root growth responses. European Journal of Soil Science, 41, 341-358. https://doi.org/ 10.1111/j.1365-2389.1990.tb00070.x

Bernardo, S., Soares, A. A., \& Mantovani, E. C. (2006). Irrigation manual (8th ed., p. 625). UFV, Brazil. Retrieved from https://www.editoraufv.com.br/busca_livraria_resultado.asp?Titulo $=\mathrm{Manual}+\mathrm{de}+\mathrm{irriga} \% \mathrm{E}$ 7\%E3o\&Tipo=Titulo\&btnBuscaLivro=Buscar

Biswas, R., Bagchi, S., Urewar, C., Gupta, D., \& Nandy, T. (2010). Treatment of wastewater from a low-temperature carbonization process industry through biological and chemical oxidation processes for recycle/reuse: A case study. Water Science \& Technology, 61(10), 2563-73. https://doi.org/10.2166/ wst.2010.181

Brouwer, R. (1962). Nutritive influences on the distribution of dry matter in the plant. Nether. Journal of Agricultural Science, 10, 342-399. Retrieved from http://ibrary.wur.nl/WebQuery/wurpubs/474058

Cardoso, E. L., Silva, M. L. N., Curi, N., Ferreira, M. M., \& de Freitas, D. A. F. (2011). Soil chemical and physical quality under natural tree vegetation and pasture in the pantanal wetlands, south of Mato Grosso, Brazil. Revista Brasileira de Ciência do Solo, 35, 613-622. https://doi.org/10.1590/S0100-06832011000200030 
Carvalho, J. J., da Luz, J. M. R., Henrique, J., Silva, J. G. D., Silva, J. E. C., \& Santos, E. A. (2018). Biofertigation of forage with effluents of green line of a cattle slaughterhouse: Microbial diversity and leaf dry mass productivity. Journal of Agricultural Science, 10(5), 353. https://doi.org/10.5539/jas.v10n5p353

Carvalho, J. J., Ribeiro, S. S., Henrique, J., \& Silva, J. G. D. (2015). Behavior of soil water infiltration at the CEULP/ULBRA campus. XV Jornada de Iniciação Científica, CEULP/ULBRA, Palmas, TO, Brazil.

CONAMA (Conselho Nacional do Meio Ambiente). (2005). Resolution number 357 of March 17, 2005. Retrieved from http://www.mma.gov.br/port/conama/res/res05/res35705.pdf

Conley, D. J., Paerl, H. W., Howarth, R. W., Boesch, D. F., Seitzinger, S. P., Karl, E., Lancelot, C., \& Gene, E. (2009). Controlling Eutrophication: Nitrogen and Phosphorus. Science, 123, 1014-1015. https://doi.org/ $10.1126 /$ science. 1167755

Costa, N. L., Moraes, A., Carvalho, P. C. F., Monteiro, A. L. G., Motta, A. C. V., \& Oliveira, R. A. (2016). Growth dynamic and forage yield of Trachypogon plumosus under levels of soil fertility correction and regrowth ages. Ciência Animal Brasileira, 17(2), 175-184. https://doi.org/10.1590/1089-6891v17i218715

Cunha, F. F., Ramos, M. M., Alencar, C. A. B., Martins, C. E., Cóser, A. C., \& Oliveira, R. A. (2010). Root system of six irrigated grasses under different nitrogen fertilization and management. Acta Scientiarum. Agronomy, 32(2), 351-357. https://doi.org/10.4025/actasciagron.v32i2.1020

Cunha, N. R. S., Lima, J. E., Gomes, M. F., \& Braga, M. J. (2008). The intensity of agricultural exploitation as an indicator of environmental degradation in the Cerrado region, Brazil. Revista de Economia e Sociologia Rural, 46(2). https://doi.org/10.1590/S0103-20032008000200002

De Bona, F. D. (2008). Nitrogen and sulfur for forage grass: Soil attributes and metabolic, nutritional and productive aspects of the plant ( $\mathrm{p}$. 124). Universidade de São Paulo, Brazil. Retrieved from http://www.teses.usp.br/teses/disponiveis/11/11140/tde-10032009.../Fabiano_Bona.pdf

Doran, J. W., \& Parkin, T. B. (1994). Defining and assessing soil quality. In J. W. Doran, D. C. Coleman, D. F. Bezdicek, \& B. A. Stewart (Eds.), Defining soil quality for a sustainable environment (pp. 3-21, SSSA Spec. Publ., 35). Madison, ASA, CCSA, SSSA. Retrieved from https://dl.sciencesocieties.org/publications/ books/tocs/sssaspecialpubl/definingsoilqua

Drudi, A., \& Braga, A. F. (1990). Levels of phosphorus, sulfur and micronutrients on degraded pasture recovery on sandy soils of north of Tocantins state. Pesquisa Agropecuária Brasileira, 25(9), 1317-1322. Retrieved from https://seer.sct.embrapa.br/index.php/pab/article/view/19476

EMBRAPA (Empresa Brasileira de Pesquisa Agropecuária). (1984). Highlight of the main research results of 1983 (p. 88).

EMBRAPA (Empresa Brasileira de Pesquisa Agropecuária). (1999). Manual of methods of soil analysis. EMBRAPA. Retrieved from https://www.agencia.cnptia.embrapa.br/Repositorio/Manual+de+Metodos_000 fzvhotqk02wx5ok0q43a0ram31wtr.pdf

EMBRAPA (Empresa Brasileira de Pesquisa Agropecuária). (2006). Brazilian system of soil classification (2nd ed., p. 306). EMBRAPA, Rio de Janeiro. Retrieved from https://www.agrolink.com.br/downloads/sistemabrasileiro-de-classificacao-dos-solos2006.pdf

FAO (Food and Agriculture Organization of the United Nations). (2005). Statistical Databases. Retrieved from http:// www.fao.org/faostat

Freire, F. M., Coelho, A. M., Viana, M. C. M., \& Silva, E. A. (2012). Nitrogen and potassium fertilization in intensive pasture production systems. Informe Agropecuário, 33, 60-68. Retrieved from http://ainfo.cnptia.embrapa.br/digital/bitstream/item/62241/1/Adubacao-nitrogenada-1.pdf

Gloaguen, T. V., Gonçalves, R. A. B., Forti, M. C., Lucas, Y., \& Montes, C. R. (2010). Irrigation with domestic wastewater: A multivariate analysis of main soil changes. Revista Brasileira de Ciência do Solo, 34, 1427-1434. https://doi.org/10.1590/S0100-06832010000400038

Gomes, B. M. F. (2010). Physical-Chemical Pretreatment of Industrial Effluents from a Cattle Slaughterhouse (p. 76). Universidade de Passo Fundo, Brazil. Retrieved from http://usuarios.upf.br/ engeamb/TCCs/2010-2/ B\%C1RBARA\%20MARIA\%20FRITZEN\%20GOMES.pdf

Gucker, B., Boechat, I. G., \& Giani, A. (2009). Impacts of agricultural land use on ecosystem structure and whole-stream metabolism of tropical Cerrado streams. Freshwater Biology, 54(10), 2069-2085. https://doi.org/10.1111/j.1365-2427.2008.02069.x 
Hespanhol, I. (2002). Water reuse potential in Brazil: Agriculture, industry, municipalities, recharge of aquifers. Revista Brasileira de Recursos Hídricos, 7(4), 75-95. Retrieved from http://biton.uspnet.usp.br/cirra/ wp-content/uploads/2013/09/Potencial.Reuso_.ABRH_.pdf

IBGE (Instituto Brasileiro de Geografia e Estatística). (2015). Municipal livestock production. Retrieved from https://www.ibge.gov.br/estatisticas-novoportal/economicas/agricultura-e-pecuaria/9107-producao-da-pecua ria-municipal.html? $=\& \mathrm{t}=\mathrm{o}$-que-e

Klank, M. (2011). Evaluation of efficacy in the treatment of liquid effluents in a cattle slaughterhouse (p. 50). Universidade Federal do Paraná, Brazil. Retrieved from http://acervodigital.ufpr.br/bitstream/handle/1884/ 39201/R\%20-\%20E\%20-\%20MARIANA\%20KLANK.pdf? sequence=1

Klar, A. E. (1991). Irrigation: Frequency and amount of application. Nobel, São Paulo.

Koura, A., Fethi, F., Lahlou, A., \& OuazzaniI, N. (2002). Reuse of urban wastewater by combined stabilization pond system en Benslimane (Marocco). Urban Water, 4, 373-378. https://doi.org/10.1016/S1462-0758 (01)00067-X

Lapen, D. R., Topp, G. C., Gregorich, E. G., \& Curnoe, W. E. (2004). Least limiting water range indicators of soil quality and corn production, Eastern Ontario, Canada. Soil \& Tillage Research, 78, 151-170. https://doi.org/10.1016/j.still.2004.02.004

Leão, T. P., Silva, A. P., Macedo, M. C. M., Imhoff, S., \& Euclides, V. P. B. (2004). Least limiting water range in the evaluation of continuous and short-duration grazing systems. Revista Brasileira de Ciência do Solo, 28, 415-423. https://doi.org/10.1590/S0100-06832004000300002

Louvet, J. N., Homeky, B., Casellas, M., Pons, M. N., \& Dagot, C. (2013). Monitoring of slaughterhouse wastewater biodegradation in a SBR using fluorescence and UV-Visible absorbance. Chemosphere, 91, 648-655. https://doi.org/10.1016/j.chemosphere.2013.01.011

Madigan, M. T., Martinko, J. M., Dunlap, P. V., \& Clark, D. P. (2010). Microbiologia de Brock (12nd ed., p. 1091). Porto Alegre: Artmed.

Malafaia, G., Araújo, F. G., Leandro, W. M., \& Rodrigues, A. S. L. (2016). Nutrient content in maize fertilized with tannery sludge vermicompost and irrigated with domestic wastewater. Revista Ambiente \& Água, 11(4). https://doi.org/10.4136/ambi-agua.1680

Malavolta, E. (1987). Manual of liming and fertilization of the main crops (p. 496). Ceres, São Paulo.

Malavolta, E., \& Kliemann, H. J. (1985). Nutritional disorders in the Cerrado (p. 136). Piracicaba: Associação Brasileira para Pesquisa da Potassa e do Fosfato.

Maldaner, T. L. (2008). Survey of alternatives to minimize the impacts generated by slaughter and refrigeration effluents (p. 69). Universidade Castelo Branco, Brazil. Retrieved from http://docplayer.com.br/1071835Levantamento-das-alternativas-de-minimizacao-dos-impactos-gerados-pelos-efluentes-de-abatedouros-e-fri gorificos.html

Masse, D. I., Masse, L., \& Bourgeois, N. (2000). Anaerobic processing of slaughterhouse wastewater in a SBR. Dairy and Swine Research and Development Centre, Agriculture and Agri-Food Canada, Quebec.

Mendes, A. C. A., Zocolotto, R., \& Nossa, V. (2006). A simulation model as a planning tool in meat cattle (p. 6). Anais do Congresso USP de Controladora e Contabilidade.

Moreira, F. M. S., \& Siqueira, J. O. (2006). Microbiology and soil biochemistry. Lavras: UFLA.

ONU. (2013), World Population Ageing (ST/ESA/SER.A/348). Department of Economic and Social Affairs, Population Division.

Pacheco, J. W. (2006). Guia técnico ambiental de abates (bovino e suíno) (p. 98). CETESB. Retrieved from http://www.cetesb.sp.gov.br

Pacheco, J. W. F., \& Yamanaka, H. T. (2008). Environmental technical guide for slaughter (bovine and pork). CETESB, São Paulo. Retrieved from http://www.fiesp.com.br/arquivo-download/?id=4260

Pimentel-Gomes, F. (2000). Course of experimental statistics (14th ed.). Esalq-USP, Piracicaba/SP, Brazil.

Primavesi, O., Corrêa, L.A., Freitas, A. R., \& Primavesi, A. C. (2008). Shallow liming on pasture of Brachiaria decumbens cv. Basilisk under heavy nitrogen fertilization. Embrapa Pecuária Sudeste. Retrieved from https://ainfo.cnptia.embrapa.br/digital/bitstream/CPPSE/18188/1/Boletim15.pdf 
Rahayu, Y. S., Walch-Liu, P., Neumann, G., Römheld, V., Von, W., \& Bangerth, F. (2005). Roodt-derived cytokinins as long-distance signals for $\mathrm{NO}_{3}{ }^{-}$induced stimulation of leaf growth. Journal of Experimental Botany, 56, 1143-1152. https://doi.org/10.1093/jxb/eri107

Raij, B., Andrade, J. C., Cantarella, H., \& Quaggio, J. A. (2001). Chemical analysis of fertility of tropical soils (p. 285). IAC, Campinas, SP, Brazil. Retrieved from http://www.iac.sp.gov.br/produtoseservicos/analisedosolo/ livro.php

Reich, P. B., Buschena, C., Tjoelker, M. G., Wrage, K., Knops, J., Tilman, D., \& Machado, J. L. (2003). Variation in growth rate and ecophysiology among 34 grasslands and savanna species under contrasting $\mathrm{N}$ supply: A test of functional group differences. New Phytologist, 157, 617-631. https://doi.org/10.1046/ j.1469-8137.2003.00703.x

Rodrigues, A. C., Silveira, J. A. G., Bonifacio, A., \& Figueiredo, M. V. B. (2013). Metabolism of nitrogen and carbon: Optimization of biological nitrogen fixation and cowpea development. Soil Biology \& Biochemistry, 67, 226-234. https://doi.org/10.1016/j.soilbio.2013.09.001

Ronquim, C. C. (2010). Soil fertility concepts and proper management for tropical regions. Embrapa, Campinas/SP. Retrieved from https://www.embrapa.br/busca-de-publicacoes/-/publicacao/882598/conceitos -de-fertilidade-do-solo-e-manejo-adequado-para-as-regioes-tropicais

Roscoe, R., Nunes, W. A. G., Sagrilo, E., \& Otsubo, A. A. (2006). Agricultural use of refrigerator waste as solid organic fertilizer (p. 30). Embrapa Agropecuária Oeste. Retrieved from http://www.infoteca.cnptia. embrapa.br/infoteca/handle/doc/254846

Santos, J. A., Santos, V. B., \& Araújo, A. S. F. (2009). Changes in soil microbial activity and organic matter after application of sewage sludge. Bioscience Journal, 25(2), 17-23. Retrieved from https://www.cabdirect.org/ cabdirect/abstract/20093334706

Scarassati, D., Carvalho, R. F., Delgado, V. L., Coneglian, C. M. R., Brito, N. N., Tonso, S., ... Pelegrini, R. (2003). Treatment of effluents from slaughterhouses and slaughterhouses. III Fórum de estudos contáveis, Claretianas. Retrieved from http://www.universoambiental.com.br/novo/artigos_ler.php?canal

SEPLAN (Secretaria de Planejamento e da Modernização da Gestão Pública do Tocantins). (2013a). Socioeconomic Indicators. Retrieved from http://www.seplan.to.gov.br/Portal/acontece/indicadores-socio economicos

SEPLAN (Secretaria de Planejamento e da Modernização da Gestão Pública do Tocantins). (2013b). Geographical Atlas of Tocantins. Retrieved from http://seplan.to.gov.br/zoneamento/atlas-do-tocantins

Silva, J. G. D. (2017). Biotechnology of use of domestic wastewater in Cerrado soil to cultivation of Brachiaria brizantha cv Marandu (p. 100). Biotecnologia e Biodiversidade da Rede Bionorte, Universidade Federal do Tocantins. Retrieved from https://repositorio.uft.edu.br/bitstream/11612/356/1/Jos\%C3\%A9\%20Geraldo\% 20Devalux\%20Silva\%20-\%20Tese.pdf

Silva, J. G. D., Carvalho, J. J. E., da Luz, J. M. R., \& da Silva, J. E. C. (2016). Fertigation with domestic wastewater: Uses and implications. African Journal of Biotechnology, 15, 20. https://doi.org/10.5897/ AJB2015.15115

Silva, J. G. D., Matos, A. T., Borges, A. C., \& Previero, C. A. (2012). Chemical-bromatological composition and productivity of Mombaça grass (Panicum maximum cv. mombaca) submitted to different primary wastewater treatments of sanitary sewage. Revista Ceres, 59, 606-613. https://doi.org/10.1590/S0034-737X20120005 00005

Silveira, D. D. (199). Model for selection of meat industry effluent treatment system. Universidade Federal de Ssanta Catarina. Retrieved from http://teses.eps.ufsc.br/defesa/pdf/2964.pdf

Sousa, E. S., Lima, F. W. B., Maciel, G. F., Sousa, J. P., \& Picanço, A. P. (2010). Water balance and climatic classification of Thornthwaite for the city of Palmas-TO. Retrieved from https://www.researchgate.net/ profile/Aurelio_Picanco/publication/267785050_Balanco_hidrico_e_classificacao_climatica_de_Thornthw aite_para_a_cidade_de_Palmas-TO/links/55f742e-108aeba1d9ef601bf.pdf

Stenberg, B. (199). Monitoring soil quality of arable land: Microbiological indicators. Soil Plant Science, 49, 1-24. https://doi.org/10.1080/09064719950135669

Tedesco, M. J., Gianello, C., Bissani, C. A., Bohnen, H., \& Volkweis, S. J. (1995). Soil analysis, plant and other minerais (2nd ed., p. 174). Universidade Federal do Rio Grande do Sul. 
Tinker, P. B., \& Nye, P. H. (2000). Solute movement in the rhizosphere. New York: Oxford University Press. Retrieved from https://global.oup.com/academic/product/solute-movement-in-the-rhizosphere-9780195124 927 ? cc $=$ br\&lang $=$ en $\&$

Tormena, C. A., Silva, A. P., \& Libardi, P. L. (1998). Characterization of the least limiting water range of an oxisol under no-tillage. Revista Brasileira de Ciência do Solo, 22, 573-581. Retrieved from http://www.scielo.br/pdf/rbcs/v22n4/02.pdf

Townsend, C. R., Costa, N. L., Pereira, R. G. A., \& Mendes, A. M. (2010). Response of degraded pastures of Brachiaria brizantha $c v$. Marandu at different levels and frequencies of soil fertilization. Embrapa, Comunicado Técnico 363. Retrieved from https://www.infoteca.cnptia.embrapa.br/bitstream/doc/884328/ $1 / \cot 363$ pastagem.pdf

Veiga, J. B., \& Serrão, E. A. S. (1994). Silvopastoral systems and animal production in the humid tropics: The experience of the Brazilian Amazon. In A. M. Peixoto (Eds.), Pastagens: Fundamentos da Exploração Racional (2nd ed., pp. 408-450). Piracicaba: FEALQ. Retrieved from http://www.scielo.br/scielo.php? script $=$ sci_nlinks\&ref $=000109 \&$ pid $=$ S0102-0935201000010002700023\&lng $=$ pt

Vieira, J. J., Ribas, M. M. F., Freitas, P. S. L., \& Francisconi Junior, J. P. (2009). Effect of the application of slaughterhouse wastewater treated on stabilization ponds on soil and corn development. Revista Pesquisa Aplicada \& Agrotecnologia, 2(1), 51-59. https://doi.org/10.5777/paet.v2i1.427

Von Sperling, M. (2005). Principle of biological treatment of wastewater (3rd ed., p. 452). Universidade Federal de Minas Gerais, Belo Horizonte.

Wu, L., Zhang, L., Shi, X., Liu, T., Peng, Y., \& Zhang, J. (2015). Analysis of the impact of reflux ratio on coupled partial nitrification-anammox for co-treatment of mature landfill leachate and domestic wastewater. Bioresource Technology, 198, 207-214. https://doi.org/10.1016/j.biortech.2015.08.072

\section{Copyrights}

Copyright for this article is retained by the author(s), with first publication rights granted to the journal.

This is an open-access article distributed under the terms and conditions of the Creative Commons Attribution license (http://creativecommons.org/licenses/by/4.0/). 